\title{
Chicagoland Single-Family Housing Characterization
}

J. Spanier, R. Scheu, L. Brand, and J. Yang Partnership for Advanced Residential Retrofit (PARR) 


\section{NOTICE}

This report was prepared as an account of work sponsored by an agency of the United States government. Neither the United States government nor any agency thereof, nor any of their employees, subcontractors or affiliated partners makes any warranty, express or implied, or assumes any legal liability or responsibility for the accuracy, completeness, or usefulness of any information, apparatus, product, or process disclosed, or represents that its use would not infringe privately owned rights. Reference herein to any specific commercial product, process, or service by trade name, trademark, manufacturer, or otherwise does not necessarily constitute or imply its endorsement, recommendation, or favoring by the United States government or any agency thereof. The views and opinions of authors expressed herein do not necessarily state or reflect those of the United States government or any agency thereof.

Available electronically at http://www.osti.gov/bridge

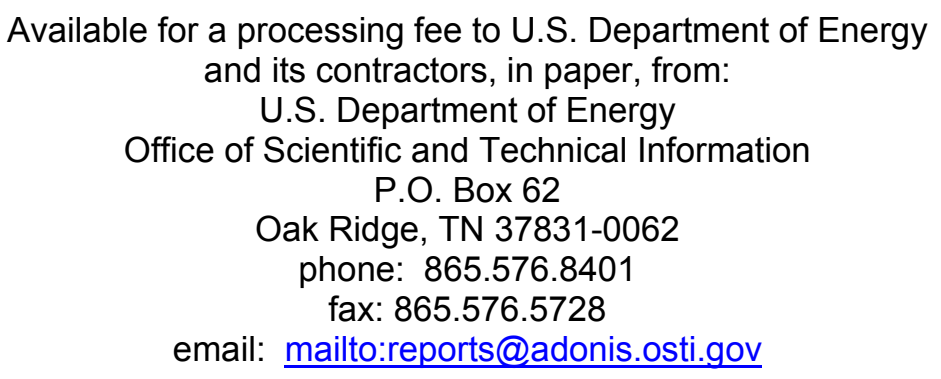

Available for sale to the public, in paper, from:

U.S. Department of Commerce

National Technical Information Service

5285 Port Royal Road

Springfield, VA 22161

phone: 800.553 .6847

fax: 703.605 .6900

email: orders@ntis.fedworld.gov

online ordering: http://www.ntis.gov/ordering.htm 


\title{
Chicagoland Single-Family Housing Characterization
}

\author{
Prepared for: \\ Building America \\ Building Technologies Program \\ Office of Energy Efficiency and Renewable Energy \\ U.S. Department of Energy \\ Prepared by: \\ J. Spanier, R. Scheu, L. Brand, J. Yang \\ CNT Energy and Gas Technology Institute for \\ Partnership for Advanced Residential Retrofit \\ 1700 South Mount Prospect Road \\ Des Plaines IL 60018 \\ Technical Monitor: Stacey Rothgeb \\ Task Order KNDJ-0-40346-02
}

June 2012 
\begin{tabular}{l|l} 
u.s. DEPARTMENT OF & Energy Efficiency \& \\
ENERCY & Renewable Energy
\end{tabular}

[This page left blank] 


\section{Contents}

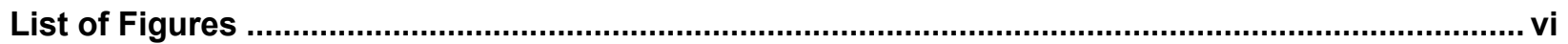

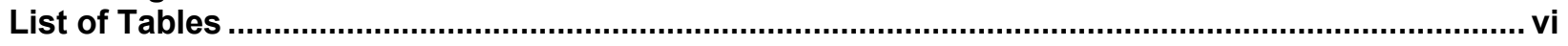

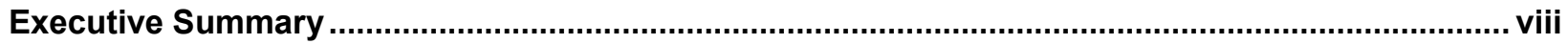

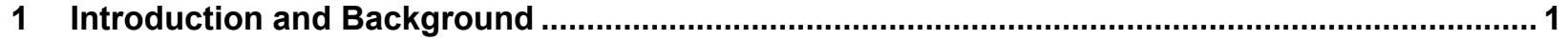

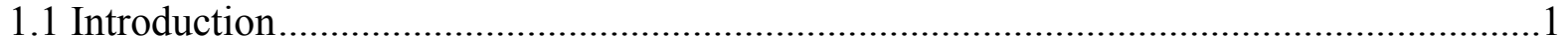

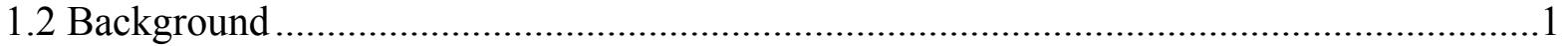

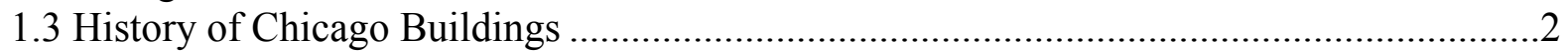

1.4 Relevance to Building America's Goals .....................................................................2

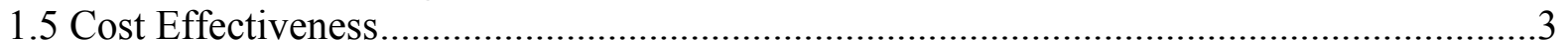

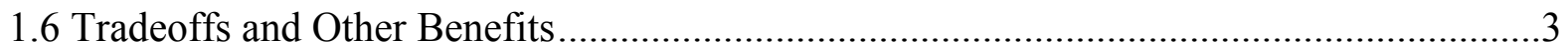

2 Objective

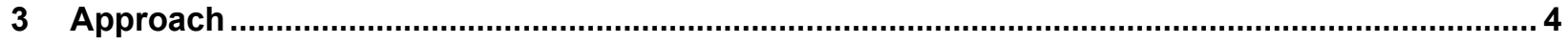

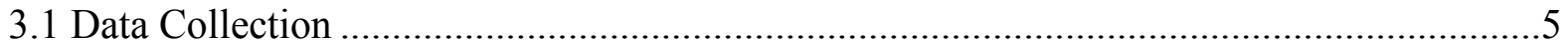

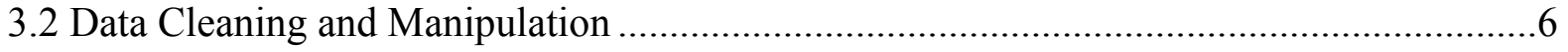

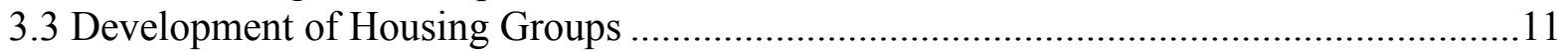

Group 1: Brick, 1978-Present, 1 to 1.5 stories (no split level) ...........................................13

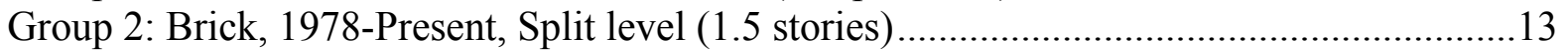

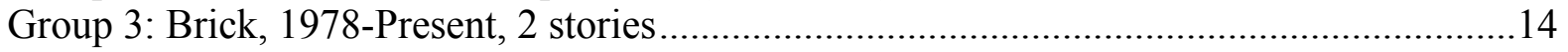

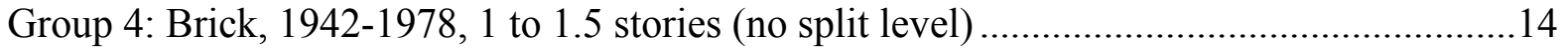

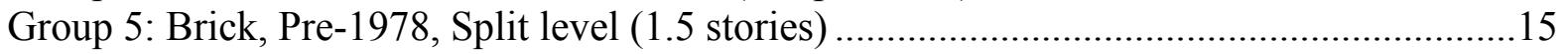

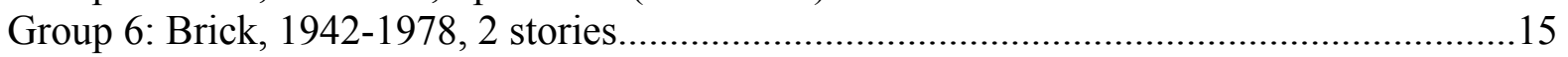

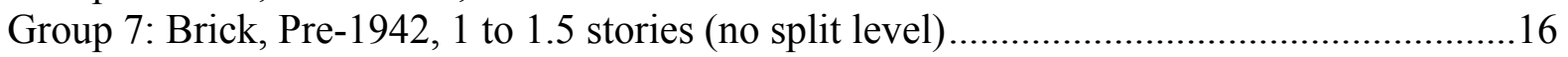

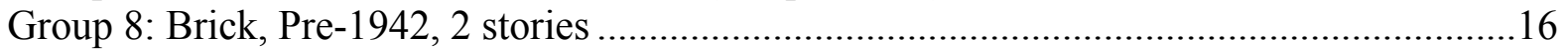

Group 9: Frame, 1978-Present, 1 to 1.5 stories (no split level) ......................................... 17

Group 10: Frame, All years, Split level (1.5 stories) ..................................................... 17

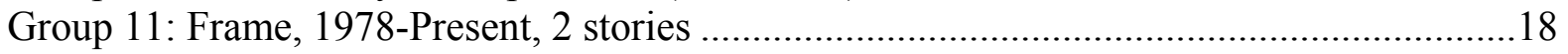

Group 12: Frame, 1942-1978, 1 to 1.5 stories (no split level) .......................................... 18

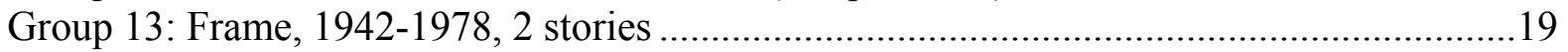

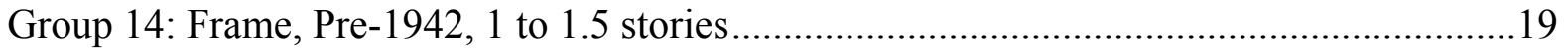

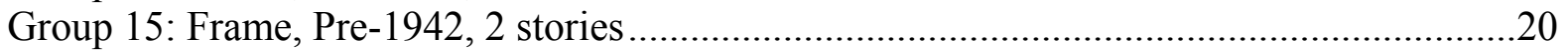

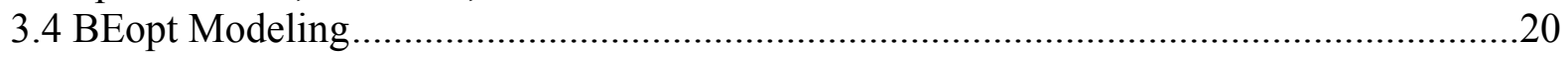

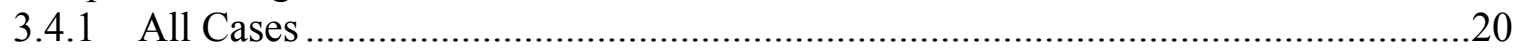

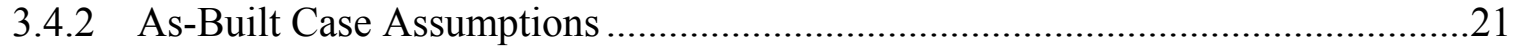

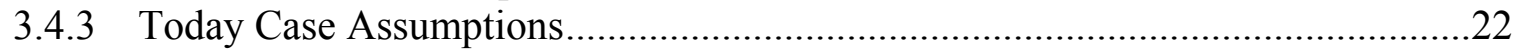

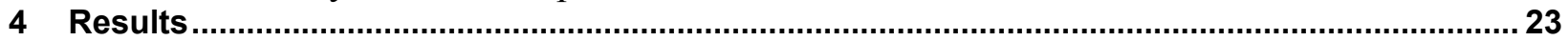

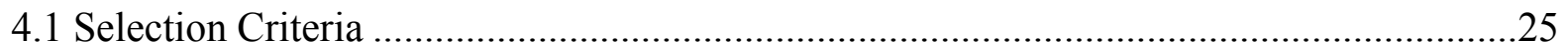

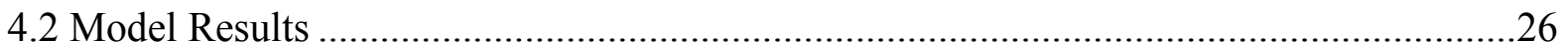

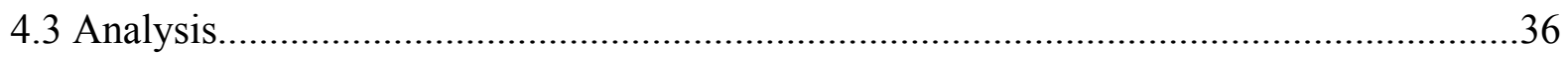

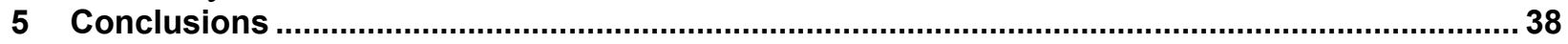

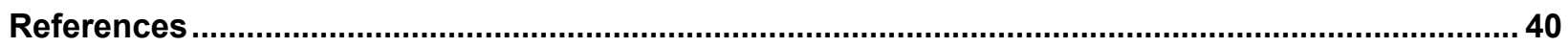

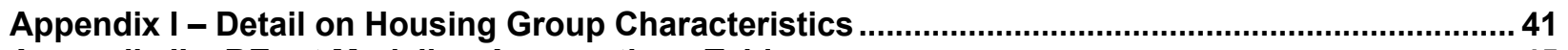

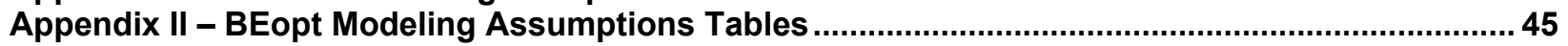

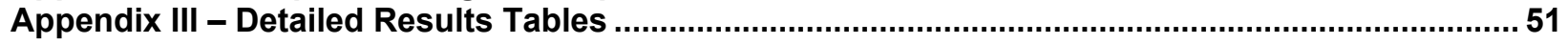




\section{List of Figures}

Figure 1. Natural gas utility service territories, Cook County, Illinois ............................................ 5

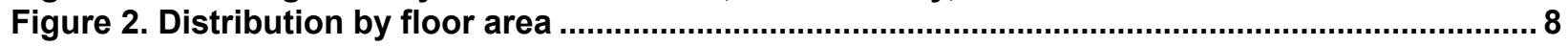

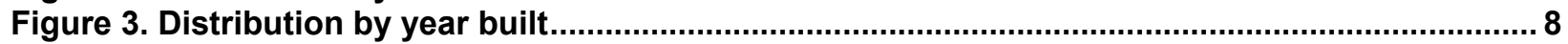

Figure 4. Source EUI from all scenarios - As-built, Today, CNT, BEopt Upgrade........................... 24

Figure 5 Therms from all scenarios - As-built, Today, CNT, BEopt Upgrade ................................. 24

Unless otherwise noted, all figures were created by the PARR team.

\section{List of Tables}

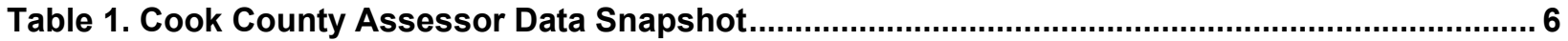

Table 2. Characteristics of General Housing Population.................................................................... 7

Table 3. Energy Statistics (presented in site energy use) ................................................................ 9

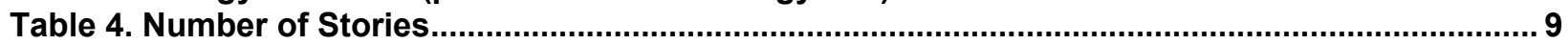

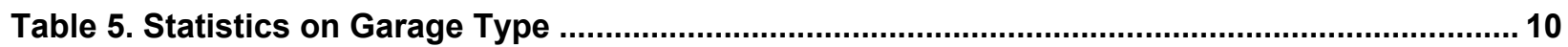

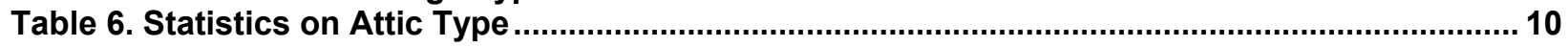

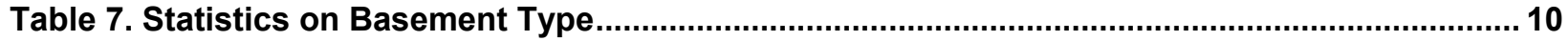

Table 8. Statistics on Energy Use by Construction Type ............................................................... 11

Table 9. Statistics on Energy Use by Year Built ...................................................................... 12

Table 10. Statistics on Energy Use by Number of Stories........................................................... 12

Table 11. BEopt Today Case Model Results by Group Compared to CNT Data.................................25

Table 12. Source EUI Reduction Percentage by Group ................................................................... 37

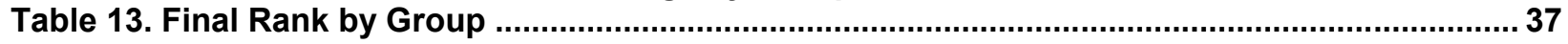

Unless otherwise noted, all tables were created by the PARR team. 


\section{Definitions}

BRC

BTU

CDD

CNT

DOE

EUI

FutEE

GTI

HDD

MEEA

MEL

PARR

RECS

TO
Building Research Council at the University of Illinois, a member of the Partnership for Advanced Residential Retrofit

British Thermal Unit is a unit of heat. 100,000 BTU equal 1 therm.

Cooling Degree Days

Center for Neighborhood Technology, an implementer of the proposed plan, currently running a portfolio of energy efficiency programs

U.S. Department of Energy, a sponsor

Energy Use Intensity is a standardized comparison for benchmarking buildings, measured in $\mathrm{kBtu}$ per $\mathrm{ft}_{2}$ per year

Future Energy Enterprise, a member of the Partnership for Advanced Residential Retrofit

Gas Technology Institute, an implementer

Heating Degree Days

Midwest Energy Efficiency Alliance, a member of the Partnership for Advanced Residential Retrofit

Miscellaneous Electrical Load

Partnership for Advanced Residential Retrofit, a Building America team led by the Gas Technology Institute

Residential Energy Consumption Survey

Task Order, referring to a time dependent work order 


\section{Executive Summary}

In this project, the PARR team identifies housing characteristics and energy use for fifteen single-family housing types (groups) in the Chicagoland region and specifies measure packages that provide an optimum level of energy savings based on a BEopt analysis. In its research, the team used property assessor data and actual energy consumption of 432,605 houses representing approximately $30 \%$ of the single-family home population. The optimum package of energy efficiency measures developed is based on a target of cost effectiveness at the measure level and $30 \%$ source energy savings. Based on the BEopt result, the project identifies the three housing groups that provide the maximum energy savings potential as defined by annual source energy savings multiplied by the total number of houses in the sample population. The three groups based on construction characteristics (structural, vintage and size) and identified as having the greatest potential as a result of this analysis are:

1. Wood frame, pre-1942 construction, 1 to 1.5 stories

2. Brick (double brick), pre-1942 construction, 1 to 1.5 stories

3. Wood frame, 1942-1978 construction, 1 to 1.5 stories.

These three housing groups will be used in the next step in the project to evaluate the measure packages. The PARR team will work with installing contractors in the field to document the upgrades that have been done to the houses since they were built, determine the cost of performing the proposed set of upgrades, and identify techniques that can be used for low-cost implementation on a community scale. ${ }^{1}$

Homeowners and efficiency program implementers require meaningful peer groups and benchmark comparisons in order to make informed upgrade decisions, and to use realistic savings estimates based on performance of a large population of similar homes of comparable size, vintage, and construction.

The segmentation methodology presented in this report is intended to be replicable in other parts of the country. Each region has varying yet distinct home characteristics (construction type, vintage and size), weather and energy regulatory environments that influence how much energy a home consumes, and upgrades that can offer the greatest energy savings. Coupling housing segmentation with measured energy data analysis for a large population of homes reduces the effect of outliers, and can significantly reduce program costs by eliminating the need for modeling each individual similarly constructed home. This replicable approach can dramatically impact how broad-scale retrofit implementation programs are developed, implemented, and brought to scale.

\footnotetext{
${ }^{1}$ Peters, Jamie, EE Solution Package for Top 3 Housing Types - Field Tests from Chicagoland Housing (to be issued later in 2012)
} 


\section{Introduction and Background}

\subsection{Introduction}

This project identifies housing characteristics and energy use for common homes in the Chicagoland region and produces advanced efficiency measure packages that can be implemented in the region's existing homes. The term "Chicagoland" is defined in this report as the city and the suburbs that make up Cook County, Illinois. Three housing types will be selected that show the best opportunity for energy savings using BEopt modeling of potential energy efficiency package options, with a target of $30 \%$ source energy savings. This savings is equivalent to between $\$ 600$ and $\$ 750$ per home per year.

The U.S. Department of Energy's (DOE) Building America program focuses on conducting research to improve the efficiency of new and existing homes. The program's overall goal is to develop integrated systems solutions that can take advantage of economies of scale.

The Partnership for Advanced Residential Retrofit (PARR) is a Building America team based in Chicago, researching energy efficiency solutions for residential housing with a focus on cold climate retrofits in the Midwest. PARR, led by GTI, represents a broad spectrum of residential building stakeholders including CNT Energy, Midwest Energy Efficiency Alliance (MEEA), Building Research Council at the University of Illinois (BRC), and Future Energy Enterprise (FutEE). These stakeholders are critical to designing, executing, and disseminating impactful research. PARR possesses strong experience in design, development, integration, and testing of advanced building energy equipment. PARR applies this experience in testing components and systems in laboratory and test house settings to improve performance, quality, and market acceptance of whole house residential energy efficiency retrofits in cold climates.

PARR was expressly created to make residential energy efficiency retrofits more cost effective and to demonstrate concepts that enable market transformation on a mass scale. PARR aims to increase the quality and uptake of residential retrofits in the midwest United States while providing Building America with systems, whole home, and community level solutions for the entire cold climate region.

Toward this goal, PARR is performing a characterization of the top fifteen housing types (groups) in Chicagoland based on assessor data, utility billing history, and available data from prior energy efficiency programs. PARR will analyze the data and recommend the housing types to focus on for designing retrofit packages using cost effectiveness of energy savings for ranking. Following this, PARR will use BEopt modeling software, paired with local cost data, to design retrofit packages for the three building types to be implemented in the field by local contractors under another PARR project

\subsection{Background}

There are more than 3.3 million single-family homes in the seven-county Chicagoland area, which represents $63 \%$ of the population of the single-family homes in Illinois. This research focuses on Cook County, the most housing-dense county in the region, where there are nearly 2 million households and 1.1 million single-family homes. The median built year of the singlefamily housing stock is 1956 , prior to implementation of energy codes requiring the installation 
of insulation. The region's extreme weather - long, cold winters and shorter hot, humid summers - combined with the older housing stock, makes homes in this region very energy intensive (nearly twice the national average), with heating being the dominant energy expenditure.

As energy costs increase, home energy improvements have the potential to keep housing affordable, improve comfort, and preserve the existing housing stock. There is significant need for cost-effective retrofit solutions that can be deployed at scale. Improving the efficiency of the region's housing can save homeowners money, improve the workforce, and strengthen the local economy. This project will identify which housing types to target and what retrofit packages offer the most cost effective energy savings.

The single-family housing stock in Cook County consists of varying types, many dating back before the Great Chicago Fire of 1871. There are more than a dozen housing types, and a dominant one is the iconic Chicago bungalow. The bungalow is a deep single-story structure with narrow street exposure, high-pitched roof, and a dormered attic space that is often converted to additional living space. Nearly 80,000 bungalows were built in the region between 1910 and 1940. These homes share similar construction features and they are ubiquitous in the region, with many blocks in neighborhoods described as part of a 'bungalow belt.' As a group, bungalows consume approximately 25\% more energy per square foot than the median home in the region, and represent huge energy savings potential. Because of their similarity, bungalows tend to require similar retrofit upgrades, such as attic air sealing and insulation. The bungalow is an example of how prescriptive retrofit packages can be customized to a specific housing type.

\subsection{History of Chicago Buildings}

The city of Chicago began as a settlement at the mouth of the Chicago River at Lake Michigan in the 1780's. Illinois reached statehood in 1818, and the city of Chicago was officially incorporated in 1832, followed by rapid growth. The great Chicago fire of 1871 destroyed the central business district and 18,000 buildings including one-third of all the residential structures. Strict building codes were instituted following the fire, favoring solid masonry construction in most commercial buildings and a large percentage of single-family and multifamily buildings well into the next century. The bungalow building era was at the center of the building boom of the early 1900's, and the current single-family building stock is significantly influenced by the construction boom in that era. Pre-1942 uninsulated wood frame and solid masonry buildings are the predominant type of construction, offering many challenges for energy efficiency retrofits.

According to 2010 U. S. census data, Cook County has a population of 5.2 million people occupying 2.2 million dwelling units. Multifamily housing accounts for $54 \%$ of the county's housing units, leaving 1.1 million single-family dwellings as the focus of this study.

\subsection{Relevance to Building America's Goals}

"The goal of the U.S. Department of Energy's (DOE) Building America program is to conduct research to develop market-ready energy solutions that improve efficiency of new and existing homes in each U.S. climate zone, while increasing comfort, safety, and durability.",

\footnotetext{
${ }^{2}$ http://www1.eere.energy.gov/buildings/building_america/program_goals.html
} 
To develop retrofit packages geared towards homes in the Chicagoland region, it is essential to know more about the structural and energy use characteristics of the homes. As a colder humid continental climate, Chicago has an average of roughly 6,500 HDD and $800 \mathrm{CDD}$. Heating is the dominant energy end use, and heat load reduction typically offers the most energy-savings potential in this region.

Part of the motivation behind this project is to increase the visibility and use of large datasets to inform program decisions and retrofit activities. These goals naturally increase the scalability of retrofits, and would serve the larger goal of increased data and knowledge about the energy use of the residential building stock in the Chicago region. This work will also provide program decision-makers with information for targeting the most cost-effective housing types in terms of energy upgrades, improving performance of public dollars and heightening the value proposition for property owners.

Further motivation is based on the rollout of Home Performance with ENERGY STAR in Illinois. This project will provide the outline of retrofit packages by home types to be used as guidance for contractors taking homes through the program.

\subsection{Cost Effectiveness}

"Many energy efficiency programs rely on energy assessments that can cost $\$ 100$ to $\$ 600$ to identify the energy saving improvements for each participating household. A less costly option is to forego an onsite home assessment, and use prescriptive approaches, offering a standard set of measures that are widely expected to save energy across a range of properties or within a specific type of targeted housing."

Large datasets help to reduce the transaction costs of analyzing and retrofitting a home. The ability to describe both the structural characteristics and energy use of a population of homes helps homeowners, assessors, contractors and policymakers make informed decisions regarding residential energy efficiency.

In addition, the data will enable modeling of a population of homes. Although customization of retrofit packages is required to retrofit an individual home, being able to do the first run of a model using data based on the population cuts down on the costs needed to model individual homes. It also enhances ability of marketers and related stakeholders to design programs that target buildings with the most potential for cost-effective energy savings.

Although the costs and savings associated with retrofitting individual homes will vary greatly depending on the measures administered to particular subjects in the sample, the retrofit packages will be cost effective as applied to the population of similar homes.

\subsection{Tradeoffs and Other Benefits}

The energy benchmarks for home types created from this research will aid in market transformation; a home with lower energy use or more potential for energy upgrades can be valued more than a comparable home without those attributes.

\footnotetext{
${ }^{3}$ Delivering Energy Efficiency to Middle Income Single Family Households," Zimring et al. Environmental Energy Technologies Division, Lawrence Berkeley National Laboratory, December 2011.
} 
In addition, these data can be used as reference for program design of future energy efficiency programs. While not included in the scope of this research, the data available can be used to spatially identify clusters of high energy use and inform targeted program design of certain geographies or communities. Through this type of characterization, it may be possible to offer energy upgrades to groups of homes without an audit; understanding from the typical energy signature how the building is built, what measures have likely already been applied, and which upgrades are cost effective going forward.

\section{Objective}

The objective of this project is to identify which of the 15 housing types (groups) to target and what retrofit packages to apply for cost-optimized energy savings that will have the largest impact in the region.

The PARR team intends to compare buildings on all of these dimensions simultaneously.

The research questions to be addressed in this project are as follows:

What are the most common housing types in Cook County?

What are the energy use characteristics of these housing types?

Can large datasets be used to identify cost-effective retrofit opportunities?

What are the types of housing to target for retrofit packages?

Do identified databases provide sufficient detail for modeling inputs?

What housing characteristics are most significant toward determining cost effectiveness of retrofit?

What is the relationship between housing type energy intensity and potential costeffective energy savings?

\section{Approach}

The approach to this project consists of four elements and the activities within each element:

- Data collection

- Data cleaning and manipulation

- Development of housing groups

- BEopt modeling.

A discussion of each element is provided in the subsections below. 


\subsection{Data Collection}

The research team gathered data from the three utilities serving the Chicago metropolitan region ${ }^{4}$. ComEd, the electric utility for northern Illinois, provided data for all residential accounts by address, including monthly kWh usage data. Integrys, the owner of People's Gas in Chicago and North Shore Gas in parts of Cook and Lake Counties, provided data for all residential accounts by address, including monthly therms usage data. Nicor Gas, the natural gas utility for northern Illinois minus the territory covered by Integrys, provided data for all residential accounts by address, including annual therms usage data.

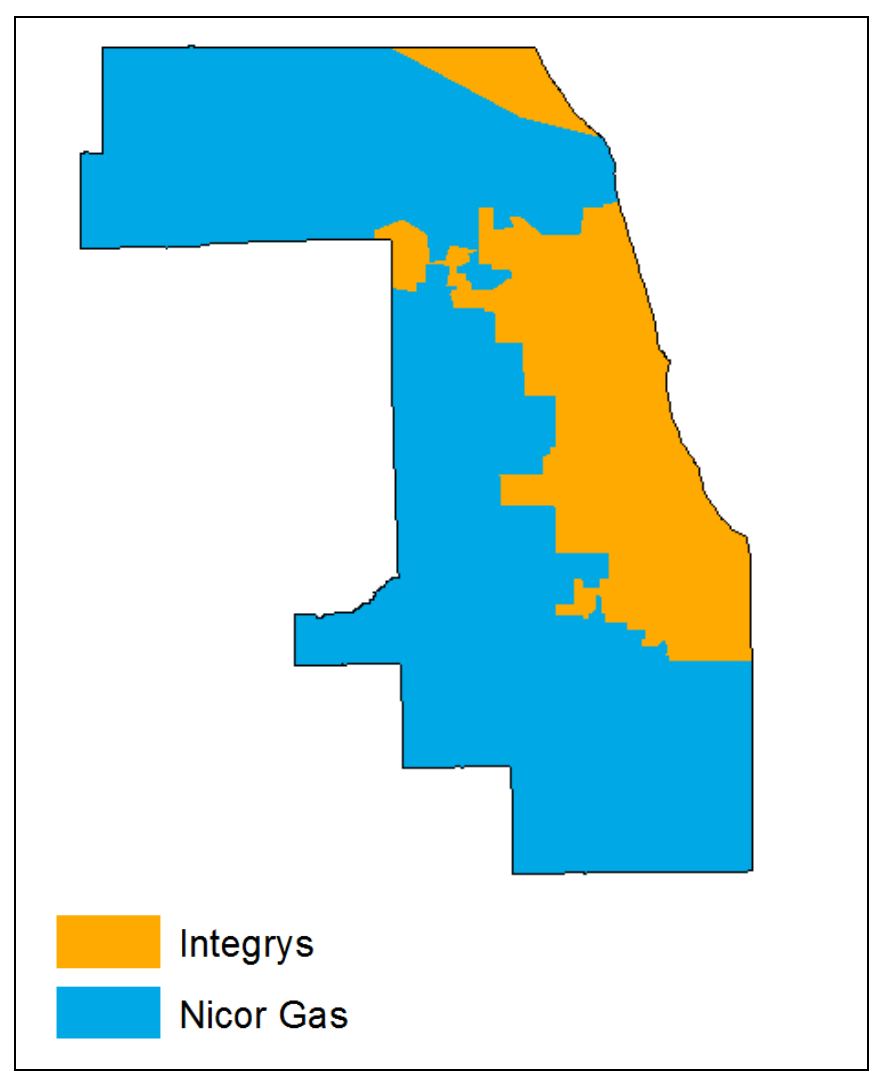

Figure 1. Natural gas utility service territories, Cook County, Illinois

In addition, PARR compiled data on residential housing stock from the Cook County assessor. The research team focused on Cook County because the assessor data on the residential housing stock is comprehensive and robust. The Cook County property assessor collects 35 data points for each home, including housing characteristics that contribute to energy usage such as exterior construction, type of attic, basement, heating and cooling systems.

\footnotetext{
${ }^{4}$ The research team matched data for calendar year 2005 in Cook County.
} 
Table 1 shows a snapshot of the data collected by the Cook County assessor.

Table 1. Cook County Assessor Data Snapshot

\begin{tabular}{|c|c|}
\hline Variable & Description \\
\hline PIN & 13-digit unique identifier \\
\hline Address & Mailing city \\
\hline City & 5-digit zip code \\
\hline ZIP & Assessor township within Cook County \\
\hline Township & Number \\
\hline Assessor class & Class is based on age, square footage, and number of units \\
\hline Number of units & Number \\
\hline Square footage & Number \\
\hline Year built & Number \\
\hline Bedrooms & Type of exterior construction \\
\hline Bathrooms (full) & Type of roof construction \\
\hline Bathrooms (half) & Type of basement \\
\hline Exterior Construction & Type of attic \\
\hline Roof & Type of heating system \\
\hline Basement & Type of air conditioning system \\
\hline Attic & Number of spaces available \\
\hline Heating System & Exterior construction of garage \\
\hline Air Conditioning &
\end{tabular}

\subsection{Data Cleaning and Manipulation}

PARR separated base load energy use from heating and cooling load energy use using a regression model based on heating and cooling degree days. The heating and cooling energy use was then weather-normalized to ensure comparisons to future energy use or other normalized models was as accurate as possible. Other normalizations, such as for occupancy, were not done because of a lack of data at the household level.

Data including housing characteristics, electric, and natural gas data compiled by address, to create a complete dataset by individual home. Because of the unique address formatting styles particular to each dataset (ex. Ave vs. Avenue), address cleaning was required.

Address cleaning was performed through a series of Perl scripts making heavy use of the language's regular expressions capabilities to identify, split, and extract complex character sequences. The output files from the cleaning process were imported into a MySQL database, and queries to that database were used to match addresses across data sources. 
This left a dataset of 464,745 homes, representing $43 \%$ of the population of nearly 1.1 million homes. Outliers were removed using the following criteria.

- Homes with missing data, including energy use, square footage, year built, or number of stories. If a home was missing at least one piece of data, it was excluded from analysis.

- Homes with assessor codes 211 and 212 were deleted, to exclude:

- 211: Two to six apartments, over 62 years

- Mixed commercial/residential building, six units or less, less than 20,000 sq. ft.

- Homes not meeting criteria for minimum energy usage were excluded:

○ Less than 100 therms

○ Less than $100 \mathrm{kWh}$

- An energy use intensity (kBtu/sqft/year) less than 30 .

- The top $1 \%$ of homes in the energy use categories were excluded to minimize the impact of high-use outliers:

○ More than 3,246 therms annually

○ More than 28,244 kWh annually

○ An energy use intensity (kBtu/sqft/year) more than 285.

After eliminating missing data and outliers, 432,605 homes were included in analysis.

A summary of the characteristics of the general population is presented in Table 2, below.

Figure 2 shows the distribution of housing by size.

Figure 3 shows the distribution by year of construction.

Table 3 provides energy statistics.

Table 2. Characteristics of General Housing Population

\begin{tabular}{|l|r|r|r|r|}
\hline Variable & Mean & Std Dev & Median & Quartile Range \\
\hline Square footage & 1426.8 & 588.0 & 1248.0 & 570.0 \\
Year built & 1951.4 & 25.3 & 1956.0 & 36.0 \\
Number of bedrooms & 3.1 & 0.8 & 3.0 & 0.0 \\
Number of full bathrooms & 1.3 & 0.5 & 1.0 & 1.0 \\
Number of half bathrooms & 0.4 & 0.5 & 0.0 & 1.0 \\
\hline
\end{tabular}




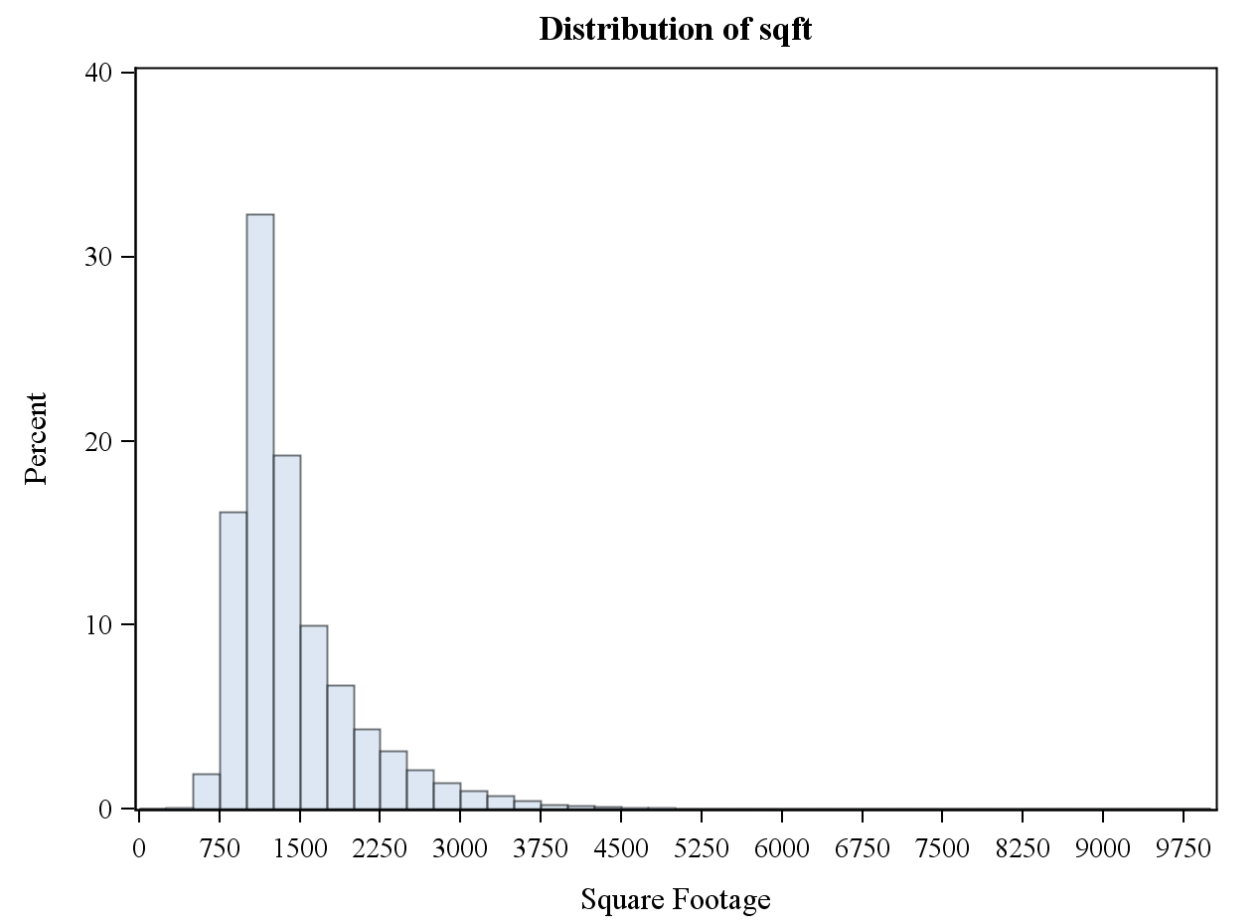

Figure 2. Distribution by floor area

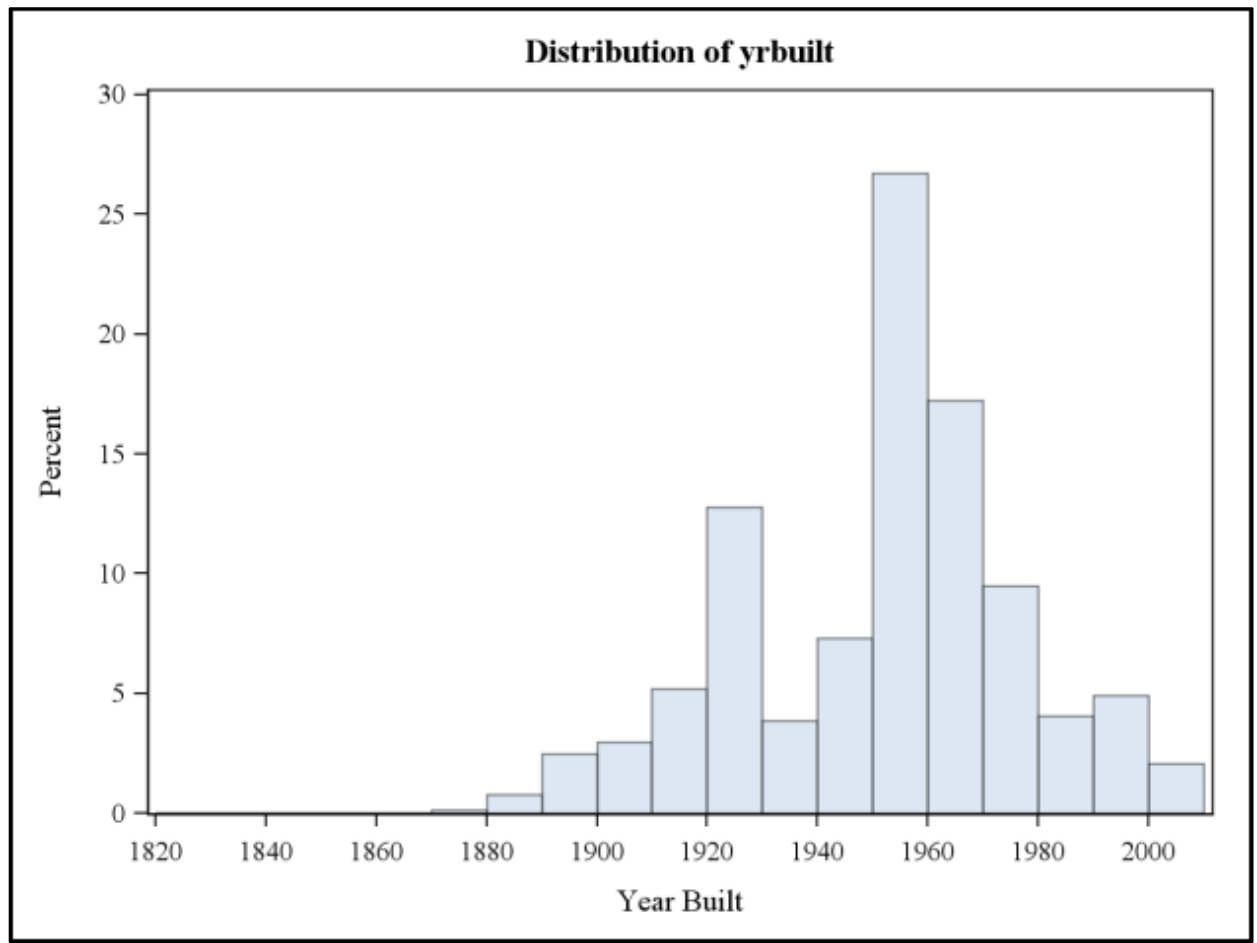

Figure 3. Distribution by year built 
Table 3. Energy Statistics (presented in site energy use)

\begin{tabular}{|l|r|r|r|r|}
\hline Variable & Mean & Std Dev & Median & Quartile Range \\
\hline Energy Use Intensity (kBtu/sqft/yr) & 130 & 44 & 125 & 58 \\
kBtu & 171,465 & 52,077 & 164,589 & 64,883 \\
Therms & 1,392 & 446 & 1,329 & 553 \\
kWh & 9,466 & 4,508 & 8,697 & 5,602 \\
Baseload (therms) & 307 & 125 & 287 & 143 \\
Heating load (therms) & 1,085 & 368 & 1,027 & 446 \\
Baseload (kWh) & 8,523 & 4,255 & 7,742 & 5,177 \\
Cooling load (kWh) & 943 & 884 & 722 & 1,039 \\
\hline
\end{tabular}

Table 4 provides statistics on number of stories. The assessor categorizes stories as the number of floors above ground level with finished space. This includes 1-, 1.5-, and 2-story classifications. For example, the vernacular Chicago Bungalow, built with an unfinished attic on the second floor with a pitched roof and knee walls, is classified as a 1-story building in the assessor data.

Table 4. Number of Stories

\begin{tabular}{|r|r|r|}
\hline Stories & Frequency & Percent \\
\hline $\mathbf{1}$ & 296,170 & 68.46 \\
\hline $\mathbf{1 . 5}$ & 44,087 & 10.19 \\
\hline $\mathbf{2}$ & 92,348 & 21.35 \\
\hline
\end{tabular}

Table 5, Table 6, and Table 7 provide statistics on garage types, attic types and basement types. 
Table 5. Statistics on Garage Type

\begin{tabular}{|l|r|r|}
\hline Garage Type & Frequency & Percent \\
\hline 1 car attached & 23470 & 5.45 \\
\hline 1 car detached & 47870 & 11.11 \\
\hline 1.5 car attached & 4696 & 1.09 \\
\hline 1.5 car detached & 26311 & 6.10 \\
\hline 2 car attached & 72190 & 16.75 \\
\hline 2 car detached & 170242 & 39.50 \\
\hline 2.5 car attached & 4047 & 0.94 \\
\hline 2.5 car detached & 14220 & 3.30 \\
\hline 3 car attached & 5671 & 1.32 \\
\hline 3 car detached & 1814 & 0.42 \\
\hline 3.5 car attached & 405 & 0.09 \\
\hline 3.5 car detached & 224 & 0.05 \\
\hline 4 car attached & 195 & 0.05 \\
\hline 4 car detached & 177 & 0.04 \\
\hline None & & 13.80 \\
\hline
\end{tabular}

Table 6. Statistics on Attic Type

\begin{tabular}{|l|r|r|}
\hline Attic Type & Frequency & Percent \\
\hline Full and Living Area & 41,759 & $9.7 \%$ \\
\hline Full and Unfinished & 52,069 & $12.1 \%$ \\
\hline None & 274,063 & $63.6 \%$ \\
\hline Partial and Living Area & 14,309 & $3.3 \%$ \\
\hline Partial and Unfinished & 48,797 & $11.3 \%$ \\
\hline
\end{tabular}

Table 7. Statistics on Basement Type

\begin{tabular}{|l|r|r|}
\hline Basement Type & Frequency & Percent \\
\hline Crawl & 20,459 & 4.8 \\
\hline Full and Rec Room & 72,547 & 16.8 \\
\hline Full and Unfinished & 194,065 & 45.0 \\
\hline Partial and Rec Room & 57,896 & 13.4 \\
\hline Partial and Unfinished & 31,942 & 7.4 \\
\hline Slab & 54,102 & 12.5 \\
\hline
\end{tabular}




\subsection{Development of Housing Groups}

The test plan outlined three segmentation methodologies to create the housing groups: statistical clustering, construction characteristics, and heating characteristics. After evaluating output results using the three methodologies, PARR decided on segmentation by construction characteristics to define the 15 housing groups.

The project's initial goal was to cluster the homes into different architectural subtypes, so that the subtypes most fit for retrofitting would be identified. Statistical cluster analysis has several different methods for choosing seeds, the starting points for the cluster groups. Because of the large size of the dataset, $\mathrm{k}$-means clustering was called for. K-means clustering initially randomly generates a cluster center and selects clusters for the data points based on lowest Euclidian distance. Once all data points are assigned, the cluster averages are used for the new centers in another round of clustering based on Euclidean distance. After the re-clustering and recentering process has been repeated enough times to meet the convergence criterion, the process is finished. Unfortunately, the data did not cluster into the different architectural subtypes as was hoped. This is largely due to the overlap of home attributes such as size, age, and frame type among different architectural styles. In the end, the clustering was based on the differences in energy use amongst the homes, which, while informative, did not group homes based on structural characteristics that would enable certain types of retrofits.

The final segmentation of housing groups is based on a three tiered system of characteristics, which are chosen based on previous program knowledge and identified contributions to energy use.

Tier 1) Construction type - either brick or not brick (includes frame and "frame and brick" houses). Table 8 provides statistics on energy use by construction type.

Table 8. Statistics on Energy Use by Construction Type

\begin{tabular}{|l|l|l|l|l|l|l|}
\hline $\begin{array}{l}\text { Construction } \\
\text { Type }\end{array}$ & N Obs & Variable (measure in site energy use) & Mean & Std Dev. & Median & $\begin{array}{l}\text { Quartile } \\
\text { Range }\end{array}$ \\
\hline Brick & 232306 & $\begin{array}{l}\text { Energy Use Intensity (kBtu/sqft/year) } \\
\text { Therms } \\
\text { kWh }\end{array}$ & 125.5 & 45.6 & 118.5 & 59.0 \\
& & 1362.7 & 439.7 & 1302.0 & 547.0 \\
& 200299 & 9750.7 & 4553.1 & 8996.0 & 5706.0 \\
\hline \multirow{2}{*}{ Frame } & $\begin{array}{l}\text { Energy Use Intensity (kBtu/sqft/year) } \\
\text { Therms } \\
\text { kWh }\end{array}$ & 135.6 & 42.2 & 131.3 & 54.2 \\
& & 9136.2 & 441.3 & 1358.0 & 558.0 \\
& & & & 8357.0 & 5442.0 \\
\hline
\end{tabular}

Tier 2) Year built: based on three categories:

Pre-1942 (the bottom of the bimodal histogram)

1942-1978 (1978 is the year that building codes changed to include insulation)

Post-1978. 
Table 9 provides statistics on energy use by year built.

Table 9. Statistics on Energy Use by Year Built

\begin{tabular}{|c|c|c|c|c|c|c|}
\hline Year built & N Obs & Variable (measure in site energy use) & Mean & Std Dev & Median & $\begin{array}{l}\text { Quartile } \\
\text { Range }\end{array}$ \\
\hline Pre-1942 & 128751 & $\begin{array}{l}\text { Energy Use Intensity (kBtu/sqft/year) } \\
\text { Therms } \\
\text { kWh }\end{array}$ & $\begin{array}{r}150.0 \\
1593.0 \\
9500.6\end{array}$ & $\begin{array}{r}47.6 \\
487.3 \\
4729.8\end{array}$ & $\begin{array}{r}144.7 \\
1541.0 \\
8717.0\end{array}$ & $\begin{array}{r}66.6 \\
627.0 \\
6006.0\end{array}$ \\
\hline $\begin{array}{l}1942- \\
1978\end{array}$ & 251544 & $\begin{array}{l}\text { Energy Use Intensity (kBtu/sqft/year) } \\
\text { Therms } \\
\text { kWh }\end{array}$ & $\begin{array}{r}129.3 \\
1302.8 \\
9100.5\end{array}$ & $\begin{array}{r}38.2 \\
390.3 \\
4205.1\end{array}$ & $\begin{array}{r}124.9 \\
1253.0 \\
8399.0\end{array}$ & $\begin{array}{r}48.5 \\
479.0 \\
5218.0\end{array}$ \\
\hline Post-1978 & 52310 & $\begin{array}{l}\text { Energy Use Intensity (kBtu/sqft/year) } \\
\text { Therms } \\
\text { kWh }\end{array}$ & $\begin{array}{r}85.8 \\
1323.2 \\
11140.1\end{array}$ & $\begin{array}{r}27.3 \\
432.6 \\
4949.5\end{array}$ & $\begin{array}{r}80.6 \\
1266.0 \\
10252.0\end{array}$ & $\begin{array}{r}33.4 \\
520.0 \\
6265.0\end{array}$ \\
\hline
\end{tabular}

Tier 3) Number of stories:

2.

Number of stories was used to segment groups by size of home. The dataset in Table 10 provided for the BEopt modeling included median square footage and median therms and $\mathrm{kWh}$ for each of the 15 housing groups. The number of stories informs BEopt modeling in terms of volume and layout of the home, rather than square footage which implies size but not the spatial distribution of that size.

Table 10. Statistics on Energy Use by Number of Stories

\begin{tabular}{|c|c|c|c|c|c|c|}
\hline Stories & N Obs & Variable (measure in site energy use) & Mean & Std Dev & Median & $\begin{array}{r}\text { Quartile } \\
\text { Range }\end{array}$ \\
\hline 1 & 296170 & $\begin{array}{l}\text { Energy Use Intensity (kBtu/sqft/year) } \\
\text { Therms } \\
\text { kWh }\end{array}$ & $\begin{array}{r}139.0 \\
1330.0 \\
8794.6\end{array}$ & $\begin{array}{r}45.2 \\
419.8 \\
4155.6\end{array}$ & $\begin{array}{r}133.8 \\
1276.0 \\
8117.0\end{array}$ & $\begin{array}{r}59.5 \\
528.0 \\
5192.0\end{array}$ \\
\hline 1.5 & 44087 & $\begin{array}{l}\text { Energy Use Intensity (kBtu/sqft/year) } \\
\text { Therms } \\
\text { kWh }\end{array}$ & $\begin{array}{r}128.9 \\
1345.9 \\
9658.0\end{array}$ & $\begin{array}{r}33.6 \\
358.9 \\
3888.1\end{array}$ & $\begin{array}{r}124.8 \\
1298.0 \\
9085.0\end{array}$ & $\begin{array}{r}41.2 \\
446.0 \\
4802.0\end{array}$ \\
\hline 2 & 92348 & $\begin{array}{l}\text { Energy Use Intensity (kBtu/sqft/year) } \\
\text { Therms } \\
\text { kWh }\end{array}$ & $\begin{array}{r}102.4 \\
1611.2 \\
11528.6\end{array}$ & $\begin{array}{r}33.2 \\
494.6 \\
5183.2\end{array}$ & $\begin{array}{r}97.8 \\
1535.0 \\
10717.0\end{array}$ & $\begin{array}{r}44.3 \\
635.0 \\
6781.5\end{array}$ \\
\hline
\end{tabular}

The 15 groups were assembled by using these three tiers and overlaying houses with similar energy use and structural characteristics. A short summary of each group with example photos follows. See Appendix I for more detailed information on characteristics of each housing group. 


\section{Group 1: Brick, 1978-Present, 1 to 1.5 stories (no split level)}

\section{$2.5 \%$ of population}

Mean Site EUI: 81.8

Mean therms: 1077

Mean kWh: 8887

Mean finished square footage: 1741

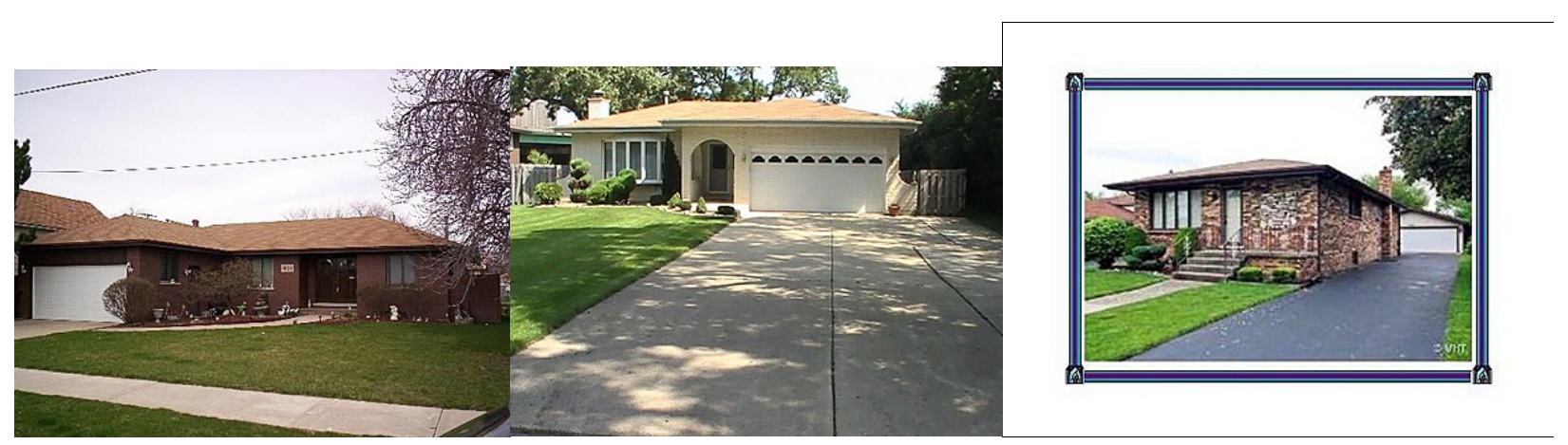

\section{Group 2: Brick, 1978-Present, Split level (1.5 stories)}

\section{$1.9 \%$ of population}

Mean Site EUI: 112.6

Mean therms: 1205

Mean kWh: 10076

Mean finished square footage: 1404

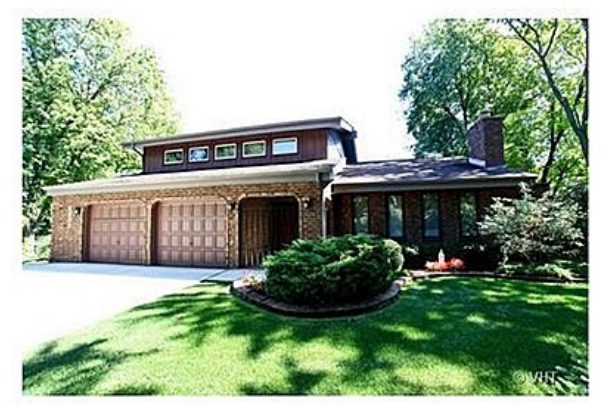




\section{Group 3: Brick, 1978-Present, 2 stories}

$4.7 \%$ of population

Mean Site EUI: 76.7

Mean therms: 1446

Mean kWh: 12482

Mean finished square footage: 2506
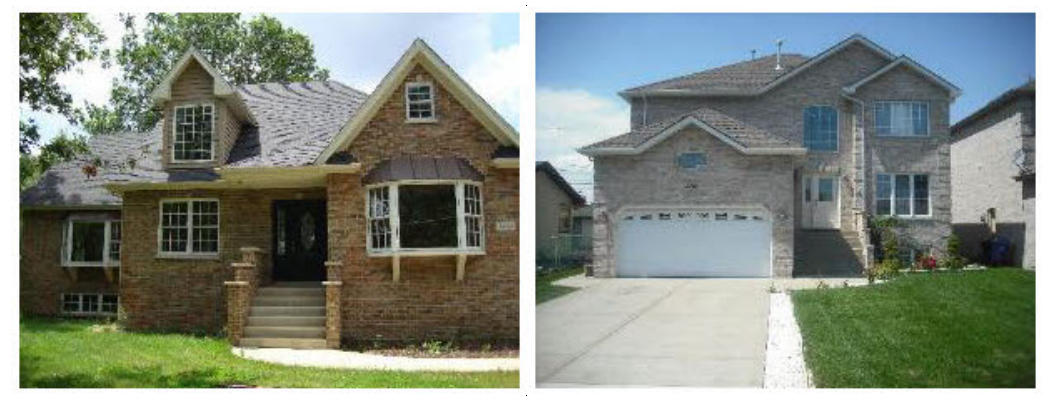

Group 4: Brick, 1942-1978, 1 to 1.5 stories (no split level)

$17.9 \%$ of population

Mean Site EUI: 129.6

Mean therms: 1212

Mean kWh: 8859

Mean finished square footage: 1217
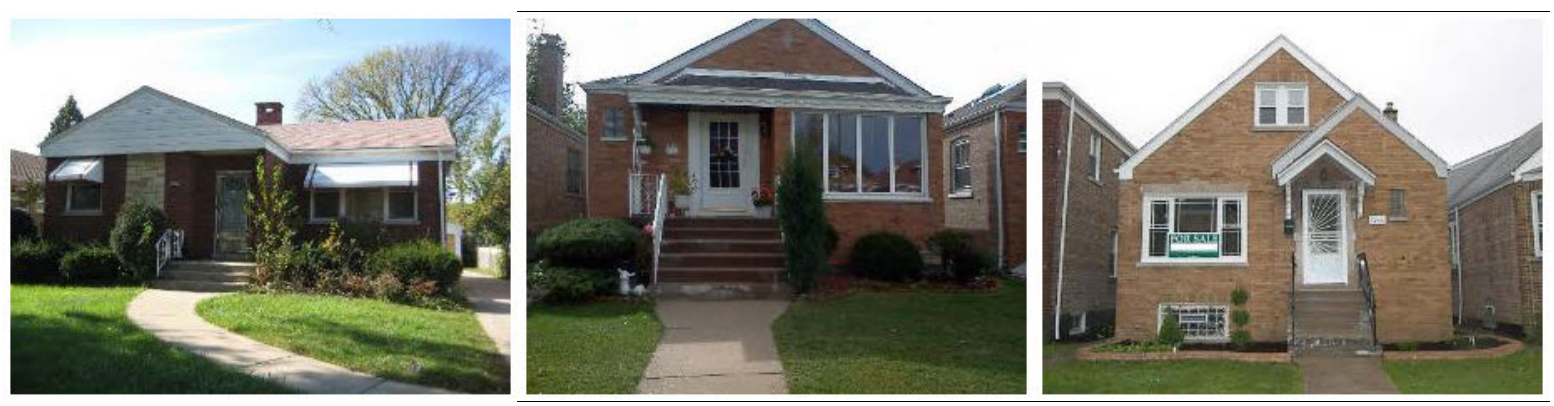
Group 5: Brick, Pre-1978, Split level (1.5 stories)

$6.1 \%$ of population

Mean Site EUI: 131.5

Mean therms: 1344

Mean kWh: 9643

Mean finished square footage: 1299
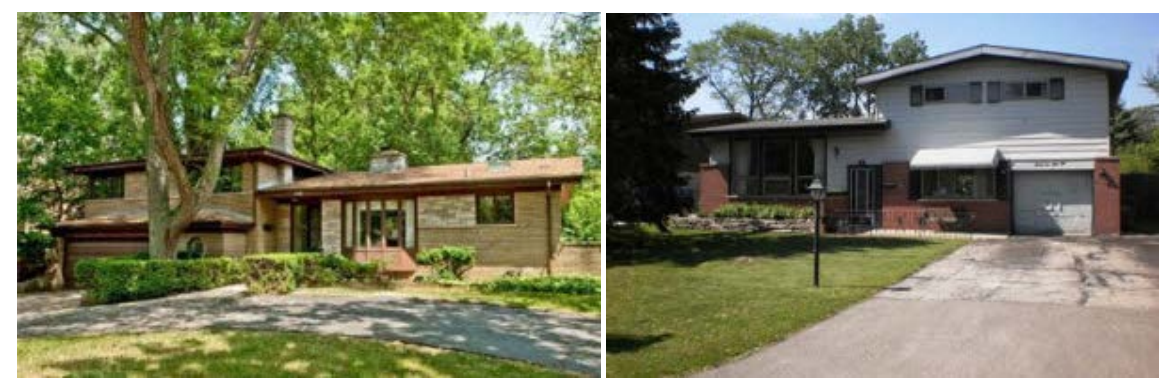

Group 6: Brick, 1942-1978, 2 stories

$4.8 \%$ of population

Mean Site EUI: 99.8

Mean therms: 1553

Mean kWh: 11714

Mean finished square footage: 2059
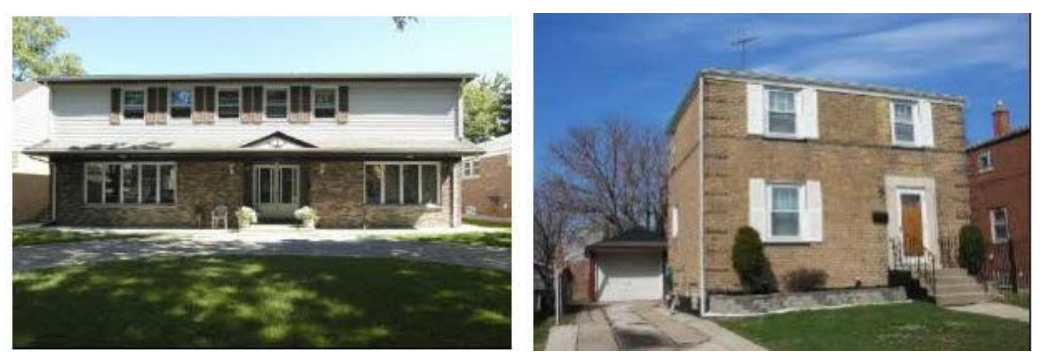


\section{Group 7: Brick, Pre-1942, 1 to 1.5 stories (no split level)}

$11.6 \%$ of population

Mean Site EUI: 161.3

Mean therms: 1442

Mean kWh: 8927

Mean finished square footage: 1141

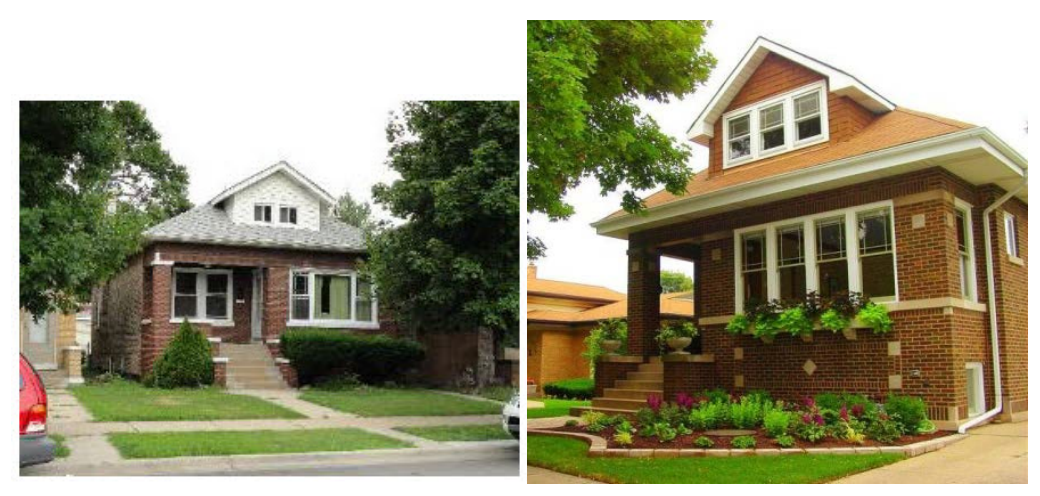

\section{Group 8: Brick, Pre-1942, 2 stories}

$4.1 \%$ of population

Mean Site EUI: 117.3

Mean therms: 1757

Mean kWh: 11062

Mean finished square footage: 1884
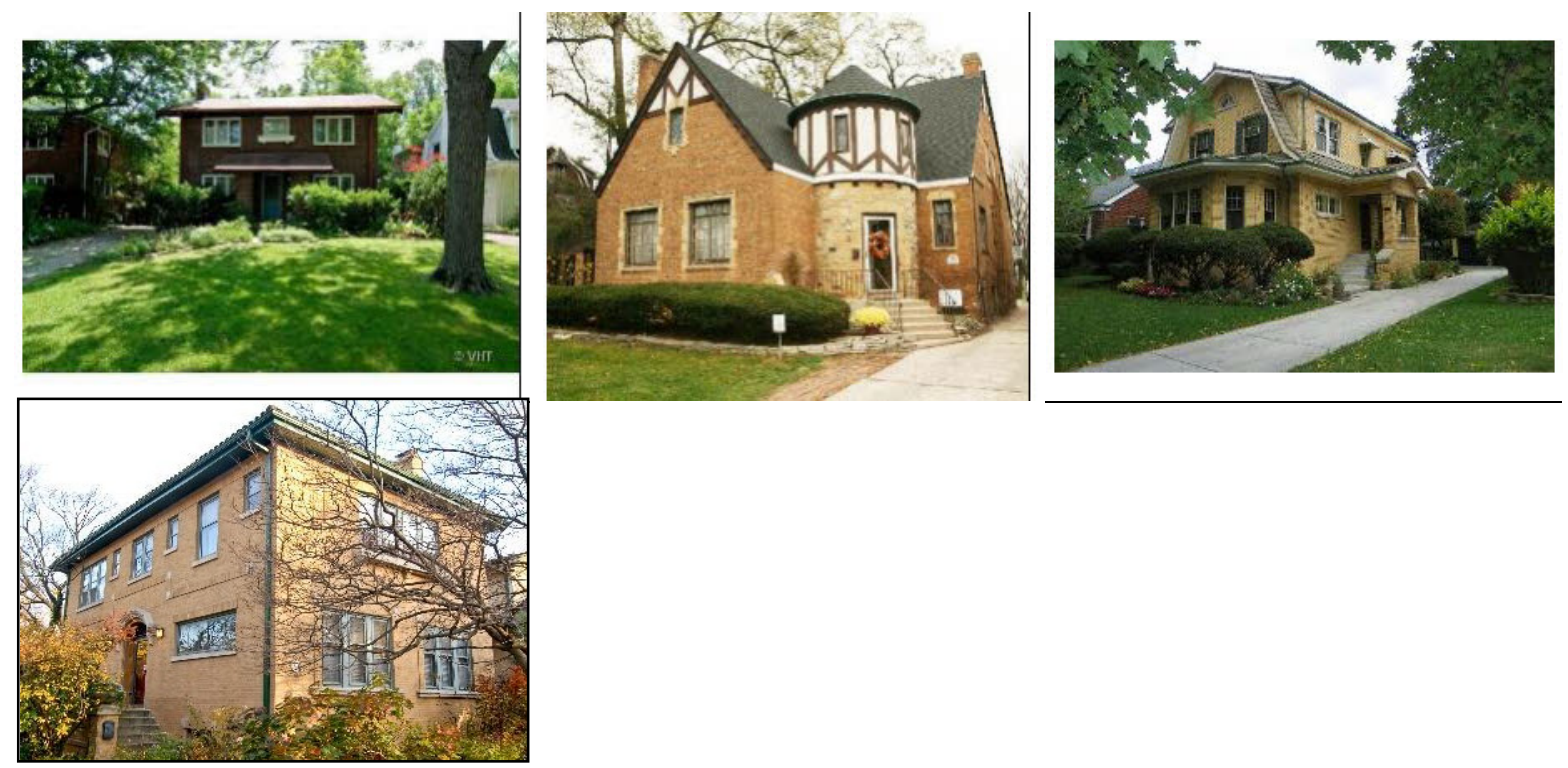


\section{Group 9: Frame, 1978-Present, 1 to 1.5 stories (no split level)}

$1.7 \%$ of population

Mean Site EUI: 91.8

Mean therms: 1217

Mean kWh: 9719

Mean finished square footage: 1801
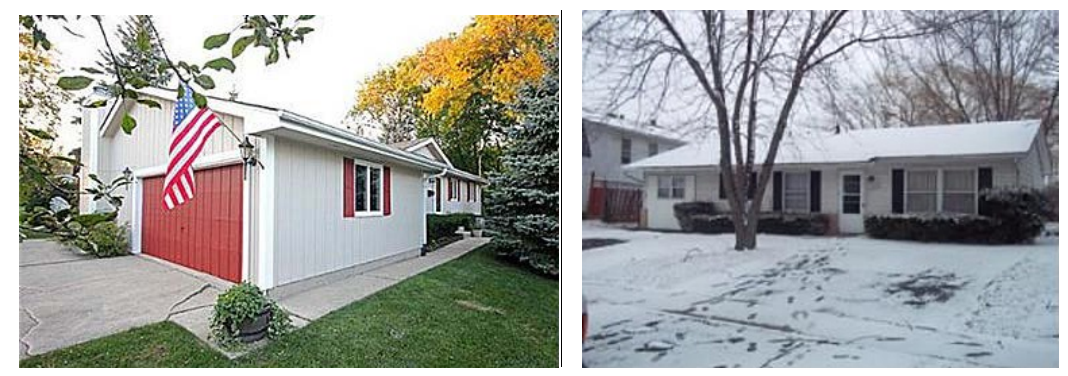

Group 10: Frame, All years, Split level (1.5 stories)

$2.1 \%$ of population

Mean Site EUI: 136.6

Mean therms: 1480

Mean kWh: 9321

Mean finished square footage: 1349
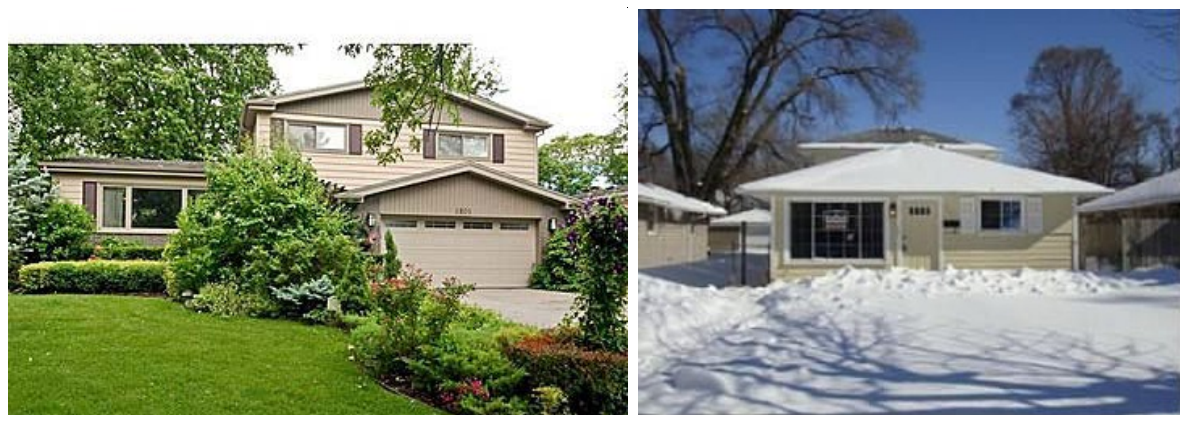


\section{Group 11: Frame, 1978-Present, 2 stories}

$1.1 \%$ of population

Mean Site EUI: 73.8

Mean therms: 1749

Mean kWh: 14914

Mean finished square footage: 3178
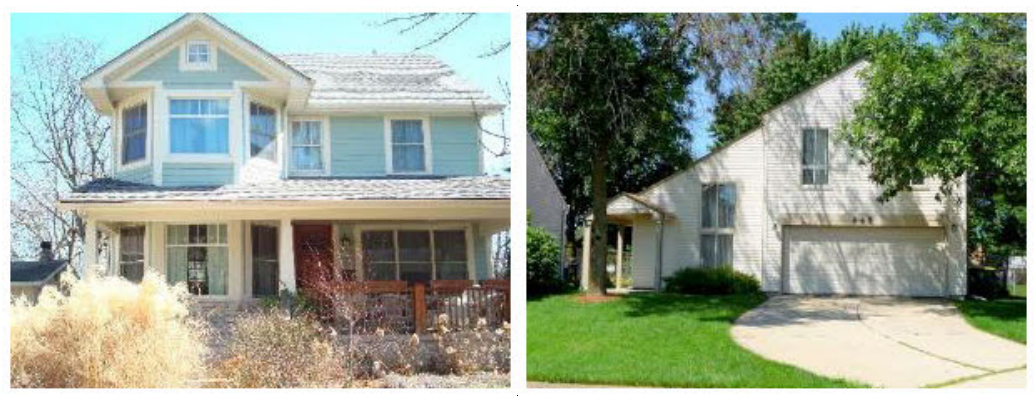

Group 12: Frame, 1942-1978, 1 to 1.5 stories (no split level)

$23.6 \%$ of population

Mean Site EUI: 135.3

Mean therms: 1268

Mean kWh: 8483

Mean finished square footage: 1185
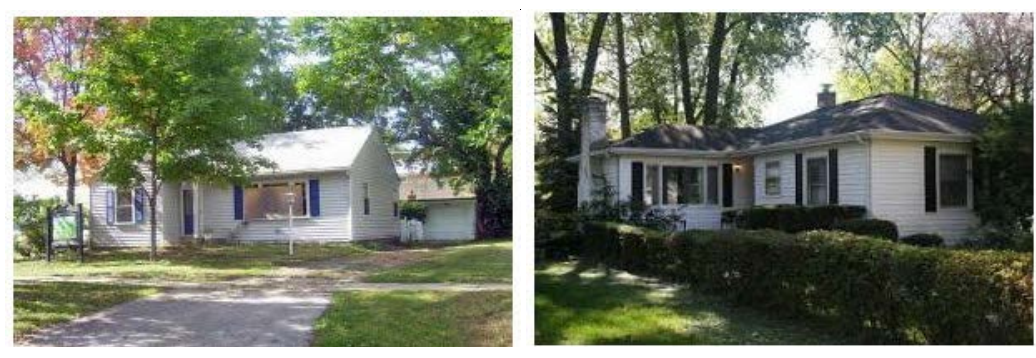


\section{Group 13: Frame, 1942-1978, 2 stories}

$3.8 \%$ of population

Mean Site EUI: 119.2

Mean therms: 1467

Mean kWh: 9802

Mean finished square footage: 1586
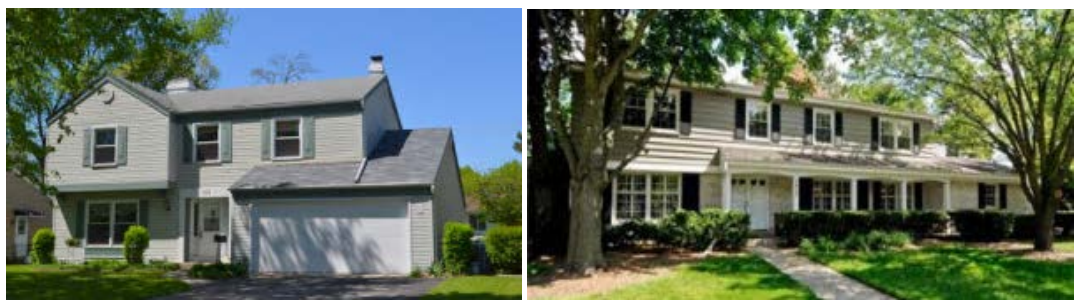

Group 14: Frame, Pre-1942, 1 to 1.5 stories

$11.2 \%$ of population

Mean Site EUI: 158.9

Mean therms: 1608

Mean kWh: 9050

Mean finished square footage: 1254
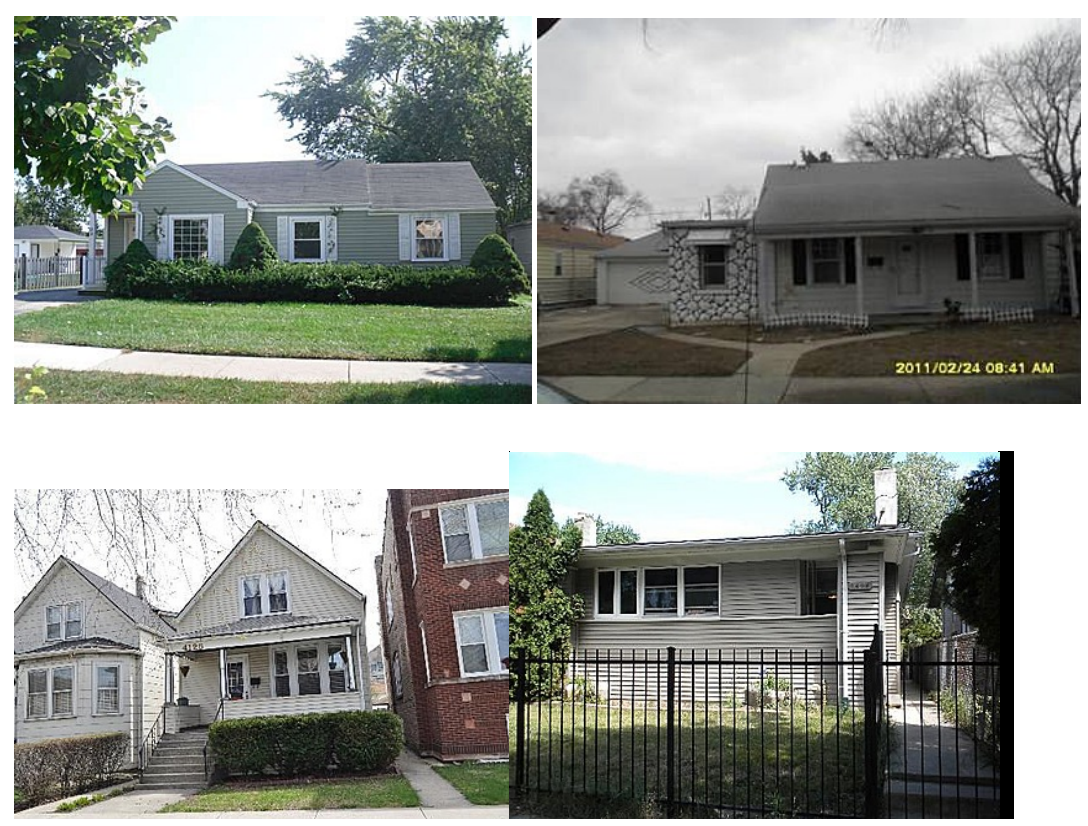
Group 15: Frame, Pre-1942, 2 stories

$2.9 \%$ of population

Mean Site EUI: 158.9

Mean therms: 1608

Mean kWh: 9050

Mean finished square footage: 2058
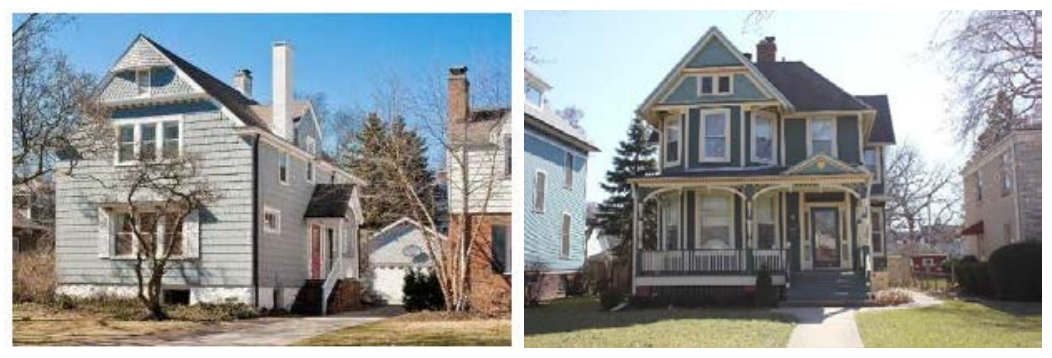

\subsection{BEopt Modeling}

The fifteen housing types (groups) identified through the data collection and analyses were then modeled using BEopt under three scenarios:

- As-built, to establish a common baseline for all groups based on year of construction, and to identify the non-upgrade characteristics of the group. This scenario was developed to document the building construction before adding expected upgrades that bring the building in line with the measured EUI data. It was useful to establish a common construction practice between housing groups by year of construction.

- Today, to apply typical upgrades in insulation, infiltration and HVAC systems in order to match the EUI energy data provided for each group.

- Upgrade, to use the optimization routines in BEopt and determine the potential energy savings through upgrade.

The PARR BEopt analyst relied on many industry experts to develop the assumptions in each of the three scenarios: an expert group consisting of PARR team members with background in weatherization training, insulation products, HVAC, and field retrofit practices; a local insulation contractor; and members of the NREL BEopt team.

Appendix II contains the assumptions made in each of the scenarios. A discussion regarding these modeling assumptions is provided in Sections 3.4.1 through 3.4.3, below.

\subsubsection{All Cases}

In all cases, PARR used the property assessor and energy data from CNT Energy to model the buildings. Number of stories, type of foundation, finished or unfinished spaces, and square footage were followed. The type of garage, number of bedrooms and baths, and type of foundation were also followed for each vintage of house. General assumptions for all vintages and scenarios are provided in the list below and specific assumptions are provided in the sections that follow. 
- Assumptions on the lot size and distance to neighbors were based on homeowner input from the PARR research team and information on the size of a standard city and suburban lot.

- In all cases, the heating setpoint was set at 70 and cooling setpoint was set at 72 and left unchanged.

- Windows were modeled as double-clear (window plus storm window) in all cases and left unchanged.

- Mechanical ventilation was modeled as none for pre-1942 and spot for other years.

- Average current appliances were chosen for the models as they were only significant in evaluating the energy use in the Today scenario.

- MEL's were set at 1 for both gas (MGL) and electric.

\subsubsection{As-Built Case Assumptions}

Pre-1942 construction assumptions were as follows:

- Brick walls pre-1942 are double brick construction. The layers from outside to inside are: 4 inch brick, 1 inch airspace (the weep space, largely mortar and bricks connecting the inside and outside layer), an inside brick layer, wood lath with no insulation in the spaces, and 5/8 inch drywall simulating plaster. A new Concrete Masonry Unit (CMU) case was developed for the weep space plus 4 inch interior brick.

- Wood frame walls pre-1942 were modeled from the outside to inside as siding, sheathing, 2x4 uninsulated walls, and 5/8 inch drywall simulating plaster on the interior wall.

- Roofs and ceilings in both types of houses were modeled as uninsulated. Bungalows were modeled with finished attic space in the upper half story. Interzonal knee walls were modeled with no insulation and the roof above the living space was also modeled with no insulation in the As-built scenario.

- Basements were uninsulated. Crawl spaces and slabs are not common in Chicago construction.

- Infiltration assumptions were as shown: very leaky for 1 story and leaky for 2 stories. These assumptions were made based on the opinion of an expert panel without validation from field data other than the close match of the Today case with field energy use intensity. The Today scenario results supported increasing the level of house tightness for all 2-story houses in all vintages. BEopt calculates infiltration in terms of ratio of the effective leakage area of the living space to the floor area of the space for the living space, basement, and garage area. The ratios for very leaky, leaky, typical, tight, tighter, and tightest (respectively) are: 0.0009, 0.0007, 0.0005, 0.00036, 0.00018, and 0.0009.

- No clothes dryer was included-line drying is the assumption.

- Boilers were the most common for pre-1942 construction and 65\% efficiency was assumed (LBNL study).

- No cooling was included in the As-built case.

- Pre-1942 gas water heating was assumed with an energy factor (EF) of 0.48 (Kelso). 
1942-1978 construction assumptions were as follows:

- For brick walls, 1 inch of R3 fiberglass was added between the furring strips.

- For wood frame and interzonal walls, an R7 fiberglass batt was the typical insulation for that era.

- Ceiling and interzonal floor insulation was R11.

- Infiltration for 1 story was upgraded to leaky and 2 stories to typical.

- Furnaces replaced boilers in the average house in this time frame; an AFUE of $70 \%$ was assumed.

- In the As-built case, cooling was not assumed for this vintage.

- The gas water heater was assumed to have the same $0.48 \mathrm{EF}$ as pre-1942.

Post-1978 construction assumptions were as follows:

- Brick walls became brick veneer - face brick on the outside of the house, followed by wood sheathing and a $2 \times 4$ stud wall with R11 insulation. The interior wall was assumed to be $1 / 2$ inch drywall.

- Wood frame walls were assumed to be the same as brick with the brick veneer replaced by white wood siding.

- Ceiling insulation was increased to R30 based on average IECC values.

- Interzonal floor insulation was increased to R19.

- Interzonal wall insulation matched the exterior wall insulation at R 11 .

- Cooling with an SEER of 10 was assumed.

- Infiltration for single story houses was set at typical and for 2-story houses was set at tight to match the results from BEopt Today measured data.

\subsubsection{Today Case Assumptions}

Each house was modified in BEopt with reasonable assumptions to reflect common energy upgrades likely made to houses over time. For example, the uninsulated pre-1942 groups had R7 insulation added to unconditioned attics to reflect an average practice, keeping in mind that many of these buildings are still operating with no insulation in the attics and many have a much higher insulation level. In every case, the MEL level was increased to 1.5 to match electric energy consumption and the water heater EF was increased to 0.54. Another option is to provide a series of models to bracket the range of energy performance characteristics of each group, but that option was rejected in favor of a single representative building. When the project moves to the field in a later task, each building will require baseline modeling to assess improvement to EUI. In addition to the assumptions above, the following assumptions were made for each vintage of building:

Pre-1942 construction upgrade assumptions were as follows:

- Attic insulation increased to R7.

- A gas dryer was added (not line drying).

- Cooling was added-SEER of 10 representing window air conditioners.

- Boiler efficiency was increased to $80 \%$, representing a 1980 's boiler.

1942-1978 construction upgrade assumptions were as follows:

- The attic insulation increased to R19. 
- Furnace efficiency was increased to $78 \%$ AFUE, the original NAECA minimum.

- Central cooling was added with an SEER of 10.

Post-1978 construction upgrade assumptions were as follows:

Furnace was upgraded to $80 \%$ AFUE to reflect some homes upgrading to high-efficiency furnaces.

In addition to these changes, several special cases were identified to improve the accuracy of the Today model for certain groups:

- Group 1 - The median year of construction for Group 1 is 1990, 1-inch foam sheathing was added to the walls, the ceiling insulation was increased to R38, and infiltration was increased from typical to tight in both the As-built and Today cases.

- Group 4 - The majority of these houses had slab floors and that model was used only here. A later vintage bungalow, a floored attic was assumed with R19 roof insulation both in the As-built and Today cases.

- Group 7 - This group is a Pre-1942 bungalow style with an upper half story in the attic. A floored attic was assumed for As-built. That assumption was not changed for the Today case because floored attics are typically not insulated beneath the floor. In this case, there were very short interzonal walls that are inaccessible and therefore uninsulated.

- Group 11 - This is the largest category of homes representing the lakeshore mansions. Electricity consumption was beyond that predicted at an MEL of 1.5. The MEL was increased to 2.0 presumably for the increased number of electronic devices.

- Group 14 - This is the only group with a full unfinished attic. A floored attic was modeled for the As-built case, typical for bungalows. For the Today case, R3 roof insulation was added to reflect an average insulation value that would be added if the attic were partially finished.

\section{Results}

The result of the BEopt modeling effort was that every group had a source EUI within $10 \%$ of the measured value provided by CNT Energy - the PARR team's goal. It must be emphasized that some of the modeling assumptions were made with the $10 \%$ agreement goal in mind, but based on reasonable insights into the group construction detail. Figure 4 shows the EUI values across the As-built, Today, CNT Energy data, and the Upgrade cases. This figure shows good agreement between modeling results and CNT Energy data, the difference between the As-built assumption and the Today assumption, and the potential for energy savings in the Upgrade case. Figure 5 shows similar comparisons for gas energy use, in therms. Gas energy use reduction drives the source EUI reduction in this cold climate. 


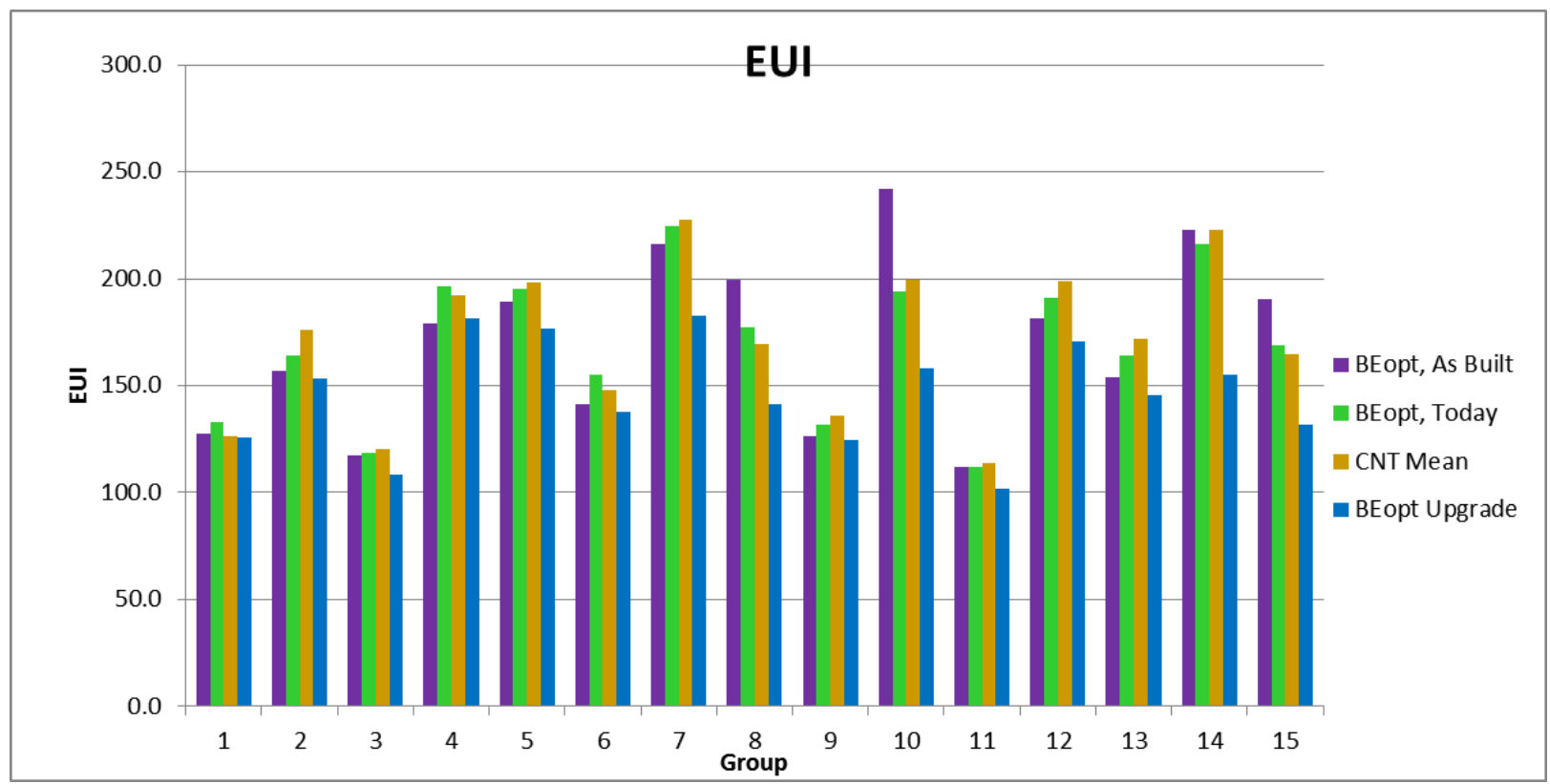

Figure 4. Source EUI from all scenarios - As-built, Today, CNT, BEopt Upgrade

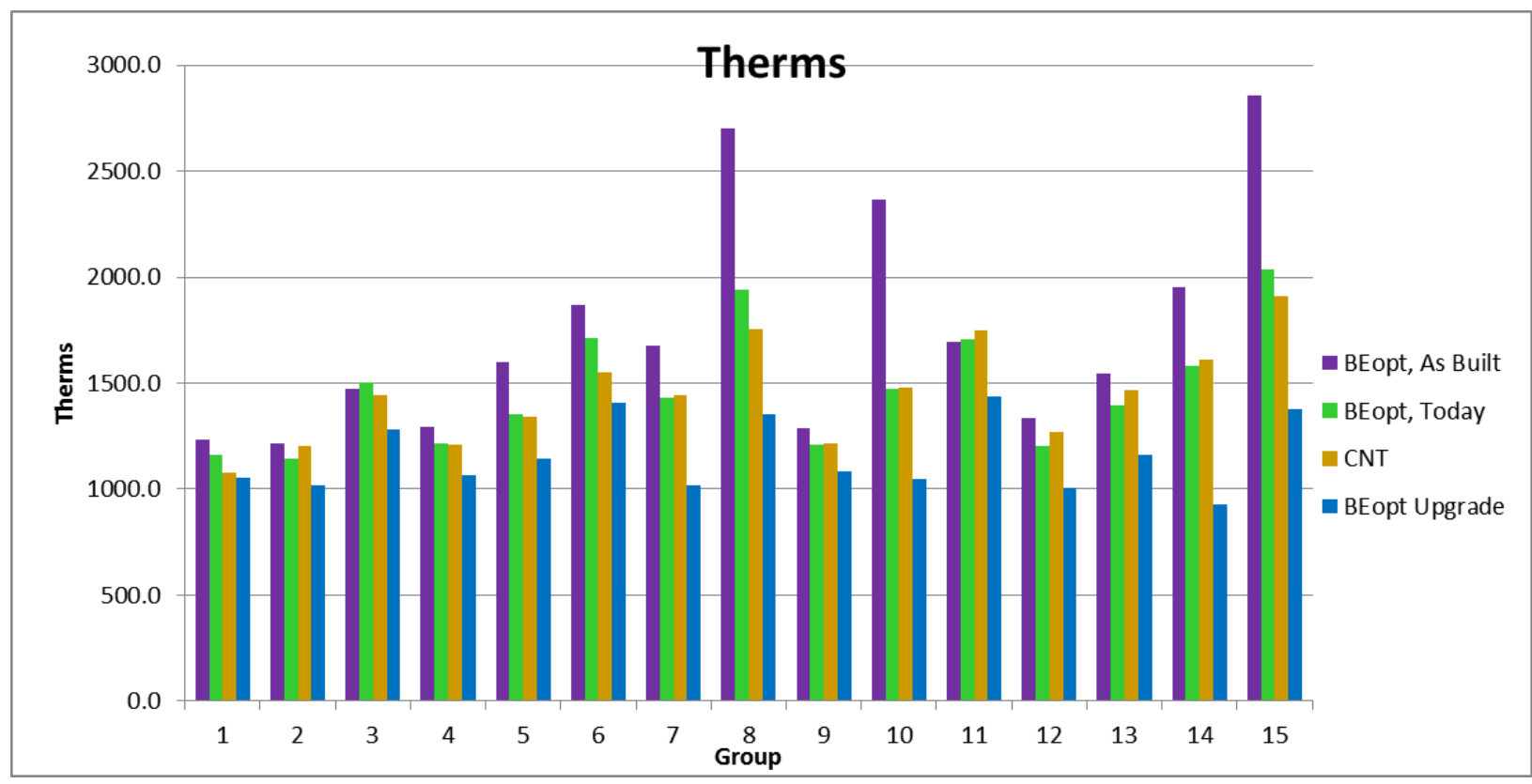

Figure 5 Therms from all scenarios - As-built, Today, CNT, BEopt Upgrade 
Table 11, below, shows the percent difference between the modeled and CNT utility data on Source EUI, Therms, and kWh. With this agreement, the project moved on to selection of the top three candidates for field implementation.

Table 11. BEopt Today Case Model Results by Group Compared to CNT Data

\begin{tabular}{|r|r|r|r|r|r|r|r|r|r|}
\hline & \multicolumn{2}{|c|}{ Source EUI, Btu/sq. ft. } & \multicolumn{3}{|c|}{ Gas in Therms } & \multicolumn{2}{c|}{ Electricity in kWh } \\
\hline GROUP & \multicolumn{1}{|c|}{$\begin{array}{l}\text { BEopt, } \\
\text { Today }\end{array}$} & $\begin{array}{c}\text { CNT } \\
\text { Mean }\end{array}$ & $\begin{array}{c}\text { Dev, } \\
\text { \% }\end{array}$ & $\begin{array}{l}\text { BEopt, } \\
\text { Today }\end{array}$ & $\begin{array}{c}\text { CNT } \\
\text { Mean }\end{array}$ & $\begin{array}{c}\text { Dev, } \\
\%\end{array}$ & $\begin{array}{c}\text { BEopt, } \\
\text { Today }\end{array}$ & $\begin{array}{r}\text { CNT } \\
\text { Mean }\end{array}$ & $\begin{array}{r}\text { Dev, } \\
\%\end{array}$ \\
\hline $\mathbf{1}$ & 132.7 & 126.2 & $5 \%$ & 1161.5 & 1077.0 & $8 \%$ & 9074.7 & 8887 & $2 \%$ \\
\hline $\mathbf{2}$ & 164.1 & 176.1 & $-7 \%$ & 1146.5 & 1205.0 & $-5 \%$ & 9159.2 & 10076 & $-9 \%$ \\
\hline $\mathbf{3}$ & 118.7 & 120.2 & $-1 \%$ & 1502.9 & 1446.0 & $4 \%$ & 11607.5 & 12482 & $-7 \%$ \\
\hline $\mathbf{4}$ & 196.4 & 192.3 & $2 \%$ & 1215.7 & 1212.0 & $0 \%$ & 9254.1 & 8859 & $4 \%$ \\
\hline $\mathbf{5}$ & 195.1 & 198.2 & $-2 \%$ & 1350.6 & 1344.0 & $0 \%$ & 9227.1 & 9643 & $-4 \%$ \\
\hline $\mathbf{6}$ & 155.2 & 147.7 & $5 \%$ & 1712.9 & 1553.0 & $10 \%$ & 11533.5 & 11714 & $-2 \%$ \\
\hline $\mathbf{7}$ & 224.7 & 227.8 & $-1 \%$ & 1430.6 & 1442.0 & $-1 \%$ & 8724.6 & 8927 & $-2 \%$ \\
\hline $\mathbf{8}$ & 177.1 & 169.3 & $5 \%$ & 1940.9 & 1757.0 & $10 \%$ & 10607.6 & 11062 & $-4 \%$ \\
\hline $\mathbf{9}$ & 132.0 & 135.7 & $-3 \%$ & 1209.5 & 1217.0 & $-1 \%$ & 9203.6 & 9719 & $-5 \%$ \\
\hline $\mathbf{1 0}$ & 193.9 & 199.1 & $-3 \%$ & 1473.6 & 1480.0 & $0 \%$ & 8771.6 & 9321 & $-6 \%$ \\
\hline $\mathbf{1 1}$ & 111.8 & 114.0 & $-2 \%$ & 1706.0 & 1749.0 & $-2 \%$ & 14733.4 & 14914 & $-1 \%$ \\
\hline $\mathbf{1 2}$ & 191.0 & 199.0 & $-4 \%$ & 1204.6 & 1268.0 & $-5 \%$ & 8256.8 & 8483 & $-3 \%$ \\
\hline $\mathbf{1 3}$ & 163.9 & 172.0 & $-5 \%$ & 1395.6 & 1467.0 & $-5 \%$ & 9367.3 & 9802 & $-4 \%$ \\
\hline $\mathbf{1 4}$ & 216.4 & 222.9 & $-3 \%$ & 1578.7 & 1608.0 & $-2 \%$ & 8624.4 & 9050 & $-5 \%$ \\
\hline $\mathbf{1 5}$ & 168.6 & 164.8 & $2 \%$ & 2034.9 & 1913.0 & $6 \%$ & 10869.8 & 11348 & $-4 \%$ \\
\hline
\end{tabular}

\subsection{Selection Criteria}

PARR identified three important criteria to use in identifying the top three housing groups to target for retrofit. They are:

- Largest potential for cost-effective retrofit

- Highest energy use intensity

- Frequency of the housing type.

The first criteria are met through the creation of BEopt retrofit packages. BEopt was given a standard list of potential retrofit measures for infiltration, ceiling or roof insulation, space heating efficiency, space cooling efficiency, and water heater efficiency. Wall insulation and window upgrades were considered but were not selected for any case due to the high cost of the measure. Space cooling efficiency upgrade was modeled for several cases but was not selected by BEopt, presumably because of the short cooling season in Chicago.

The second and third criteria are satisfied through calculating energy savings as a percentage of source EUI and using the number of houses in the calculation of total energy savings. 


\subsection{Model Results}

A description of each house and the upgrades proposed from the BEopt modeling is provided in the remainder of this section.

Group 1: Brick, 1978-Present, 1 to 1.5 stories (no split level)

Mean finished square footage: 1741

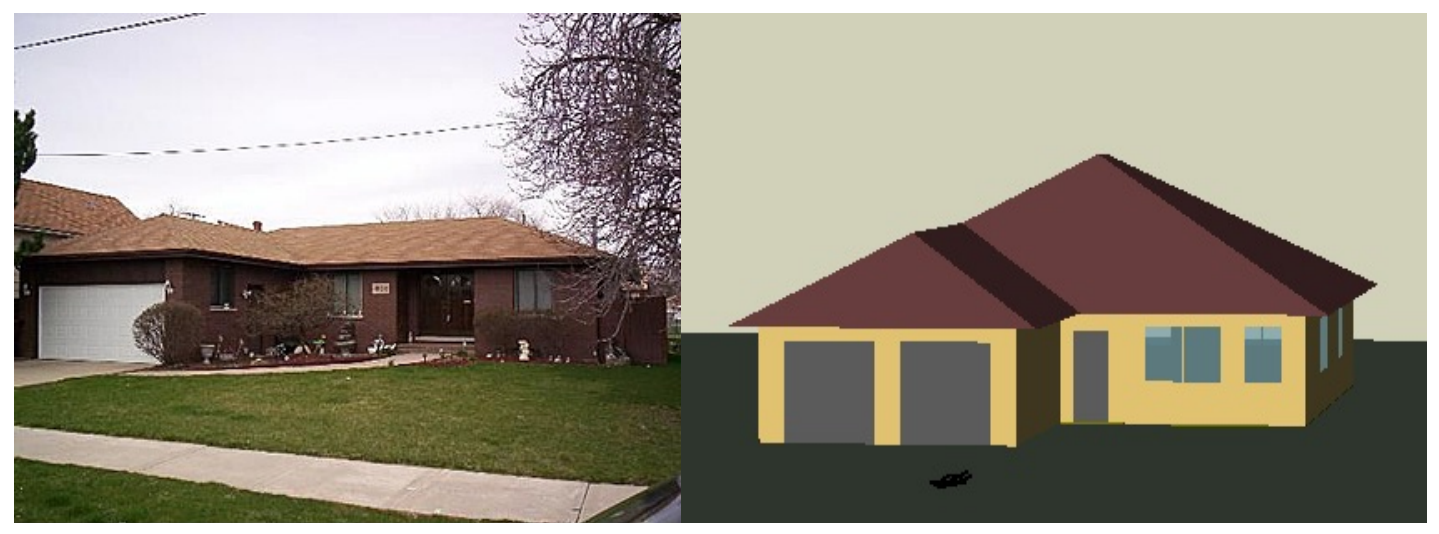

BEopt Results:

\begin{tabular}{|l|l|l|}
\hline Category & \multicolumn{1}{|c|}{ Today } & \multicolumn{1}{c|}{ Upgrade } \\
\hline Infiltration & Tight & No change \\
\hline Unfinished Attic & Ceiling R38 Fiberglass Batts, Vented & Ceiling R49 Fiberglass Blown-In, Vented \\
\hline Furnace/Boiler & Gas, AFUE $80 \%$ Furnace & No change \\
\hline Water Heater & Gas .54 EF & No change \\
\hline
\end{tabular}

Discussion:

For this group, BEopt chose increasing insulation levels in the attic as the only cost-effective upgrade, likely because this group represents the newest construction with low infiltration and good equipment efficiency.

\section{Group 2: Brick, 1978-Present, Split level (1.5 stories)}

Mean finished square footage: 1404

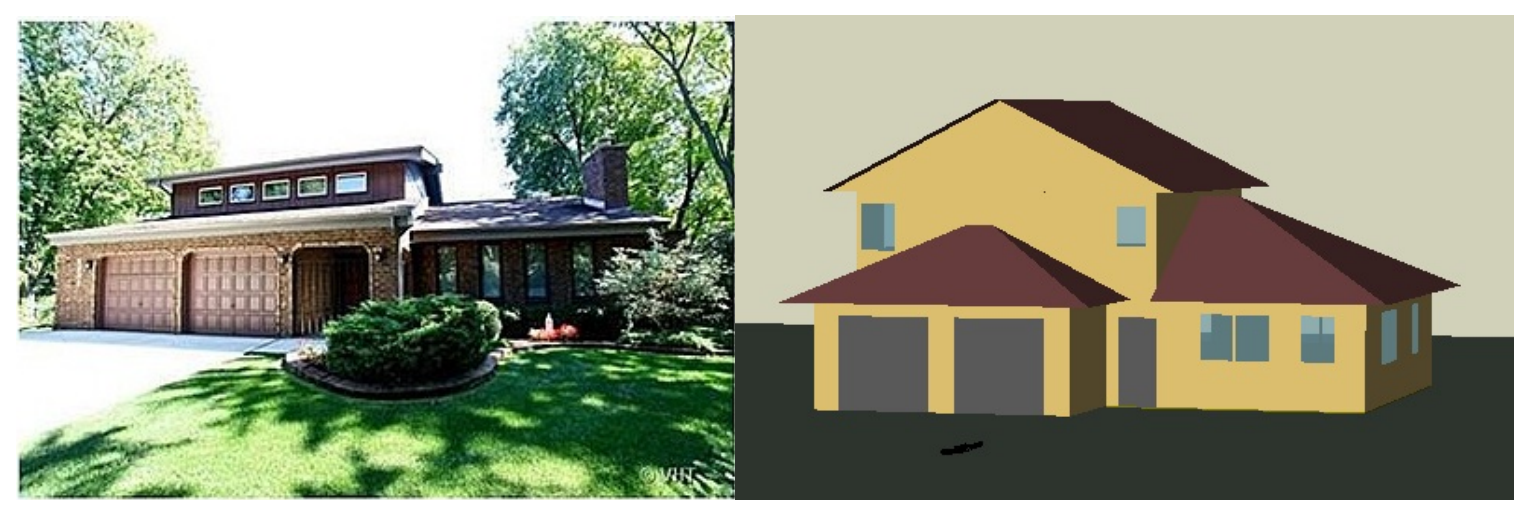


BEopt Results:

\begin{tabular}{|l|l|l|}
\hline Category & \multicolumn{1}{|c|}{ Today } & \multicolumn{1}{c|}{ Upgrade } \\
\hline Infiltration & Typical & Tight \\
\hline Unfinished Attic & Ceiling R30 Fiberglass Batts, Vented & Ceiling R38 Fiberglass Blown-In, Vented \\
\hline Furnace/Boiler & Gas, AFUE 80\% Furnace & No change \\
\hline Water Heater & Gas .54 EF & Gas Premium (0.67 EF) \\
\hline
\end{tabular}

Discussion:

For this group, BEopt chose upgrading infiltration levels to tight (Group 2 was modeled as tight) because houses above 1 story best matched their EUI when modeled as typical. Increasing attic insulation levels slightly was cost effective (adding R8 to the existing batts) to a baseline of R38 (as in Group 1) was also cost effective. Increasing water heater EF may have been chosen because of the low cost of the insulation upgrade.

Group 3: Brick, 1978-Present, 2 stories

Mean finished square footage: 2506
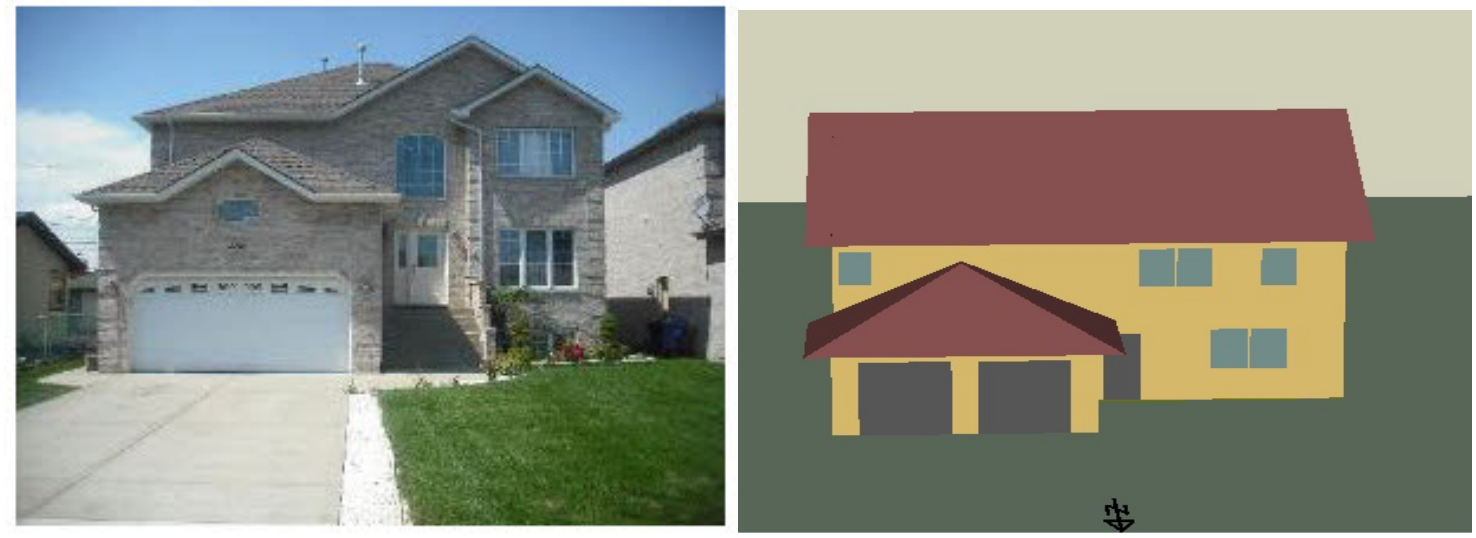

BEopt Results:

\begin{tabular}{|l|l|l|}
\hline Category & \multicolumn{1}{|c|}{ Today } & \multicolumn{1}{c|}{ Upgrade } \\
\hline Infiltration & Typical & Tight \\
\hline Unfinished Attic & Ceiling R38 Fiberglass Batts, Vented & No change \\
\hline Furnace/Boiler & Gas, AFUE 80\% Furnace & No change \\
\hline Water Heater & Gas .54 EF & Gas Premium $(0.67 \mathrm{EF})$ \\
\hline
\end{tabular}

Discussion:

For this group, BEopt chose upgrading infiltration levels to tight (Group 3 was modeled as tight) because houses above 1 story best matched their EUI when modeled as typical. Increasing attic insulation levels slightly was not cost effective likely because the R38 baseline was modeled. Increasing the water heater EF may have been chosen because of the low cost of the infiltration upgrade. 


\section{Group 4: Brick, 1942-1978, 1 to 1.5 stories (no split level)}

Mean finished square footage: 1217
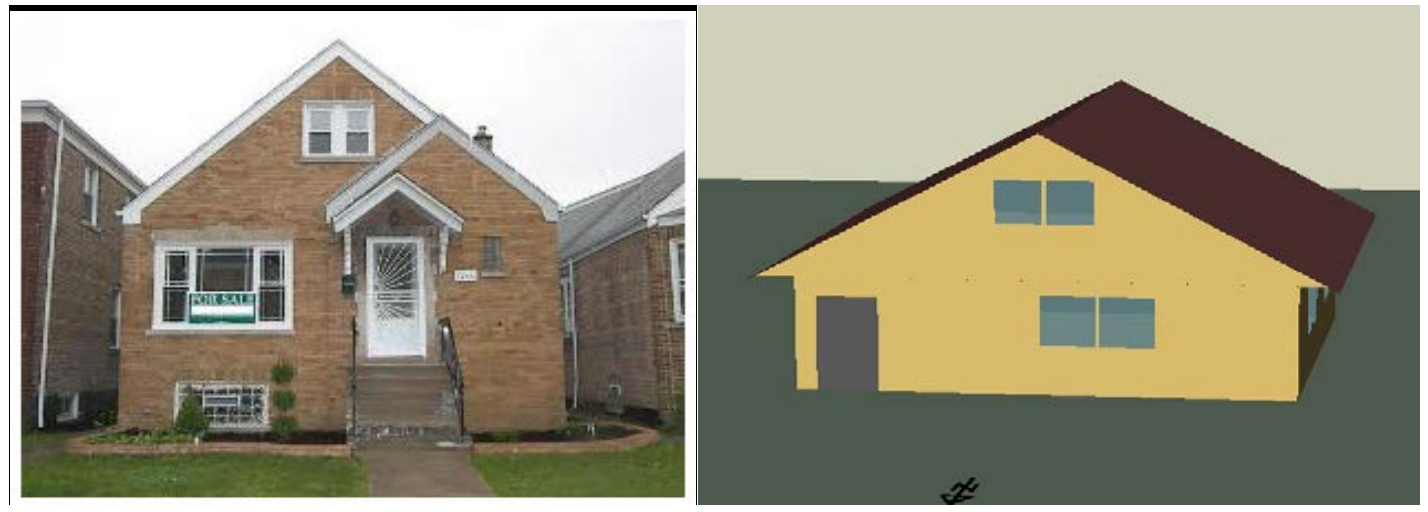

BEopt Results:

\begin{tabular}{|l|l|l|}
\hline Category & \multicolumn{1}{|c|}{ Today } & \multicolumn{1}{c|}{ Upgrade } \\
\hline Infiltration & Leaky & Typical \\
\hline Unfinished Attic & $\begin{array}{l}\text { Ceiling R19 Fiberglass Blown-In, Vented } \\
\text { Roof R19 Fiberglass }\end{array}$ & No change \\
\hline Furnace/Boiler & Gas, AFUE 78\% Furnace & No change \\
\hline Water Heater & Gas .54 EF & Gas Premium (0.67 EF) \\
\hline
\end{tabular}

Discussion:

For this 1942-1978 group, BEopt chose upgrading infiltration levels one step to typical because a two-step upgrade was not considered realistic for this vintage and was not modeled. Bungalow attic insulation was modeled as part ceiling (where the attic was not covered by the finished attic space) and part roof. The roof insulation level was constrained by the roof construction but BEopt did not choose to increase ceiling insulation, likely because of the marginal returns for the small area. Further modeling will be done in this area. Increasing the water heater EF may have been chosen because of the low cost of the infiltration upgrade.

\section{Group 5: Brick, Pre-1978, Split level (1.5 stories)}

Mean finished square footage: 1299

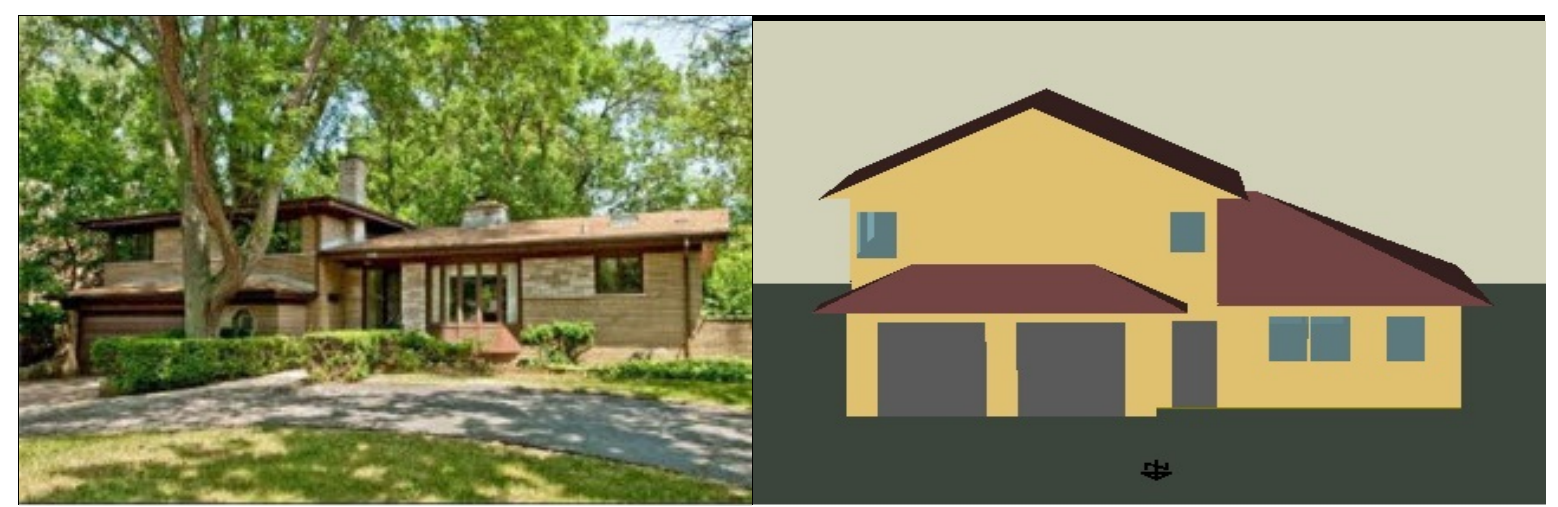


BEopt Results:

\begin{tabular}{|l|l|l|}
\hline Category & \multicolumn{1}{|c|}{ Today } & \multicolumn{1}{c|}{ Upgrade } \\
\hline Infiltration & Leaky & Typical \\
\hline Unfinished Attic & Ceiling R19 Fiberglass Blown-In, Vented & Ceiling R38 Fiberglass Blown-In, Vented \\
\hline Furnace/Boiler & Gas, AFUE 78\% Furnace & Gas, AFUE 92.5\% Furnace \\
\hline Water Heater & Gas .54 EF & No change \\
\hline
\end{tabular}

Discussion:

For this pre-1978 group, BEopt chose upgrading infiltration levels one step to typical because a two-step upgrade was not considered realistic for this vintage and was not modeled. Attic insulation was brought up to the R38 level as in some of the cases above. BEopt chose to increase the furnace efficiency in this case rather than the water heater efficiency possibly due to the large thermal envelope area compared to the floor area of the house.

Group 6: Brick, 1942-1978, 2 stories

Mean finished square footage: 2059
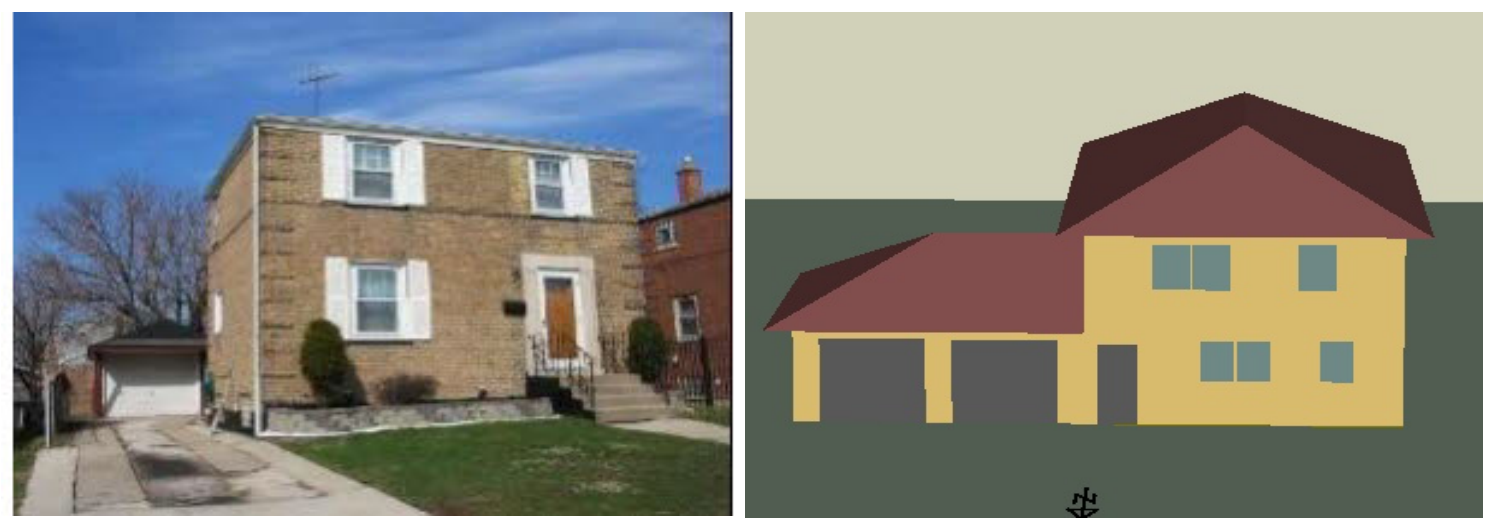

BEopt Results:

\begin{tabular}{|l|l|l|}
\hline Category & \multicolumn{1}{|c|}{ Today } & \multicolumn{1}{c|}{ Upgrade } \\
\hline Infiltration & Typical & No change \\
\hline Unfinished Attic & Ceiling R19 Fiberglass Blown-In, Vented & Ceiling R38 Fiberglass Blown-In, Vented \\
\hline Furnace/Boiler & Gas, AFUE 78\% Furnace & Gas, AFUE 92.5\% Furnace \\
\hline Water Heater & Gas .54 EF & Gas Premium (0.67 EF) \\
\hline
\end{tabular}

Discussion:

For this 1942-1978 2-story group, BEopt did not chose to upgrade infiltration but upgraded all other categories. Infiltration for this house best fit the EUI data when modeled as typical and BEopt did not chose to upgrade that level. Attic insulation was brought up to the R38 level as in some of the cases above. BEopt chose to increase the furnace efficiency in this case possibly due to the large thermal envelope area compared to the floor area of the house. Water heater efficiency was increased possibly because this is a larger house with more bedrooms and more occupants. 


\section{Group 7: Brick, Pre-1942, 1 to 1.5 stories (no split level)}

Mean finished square footage: 1141
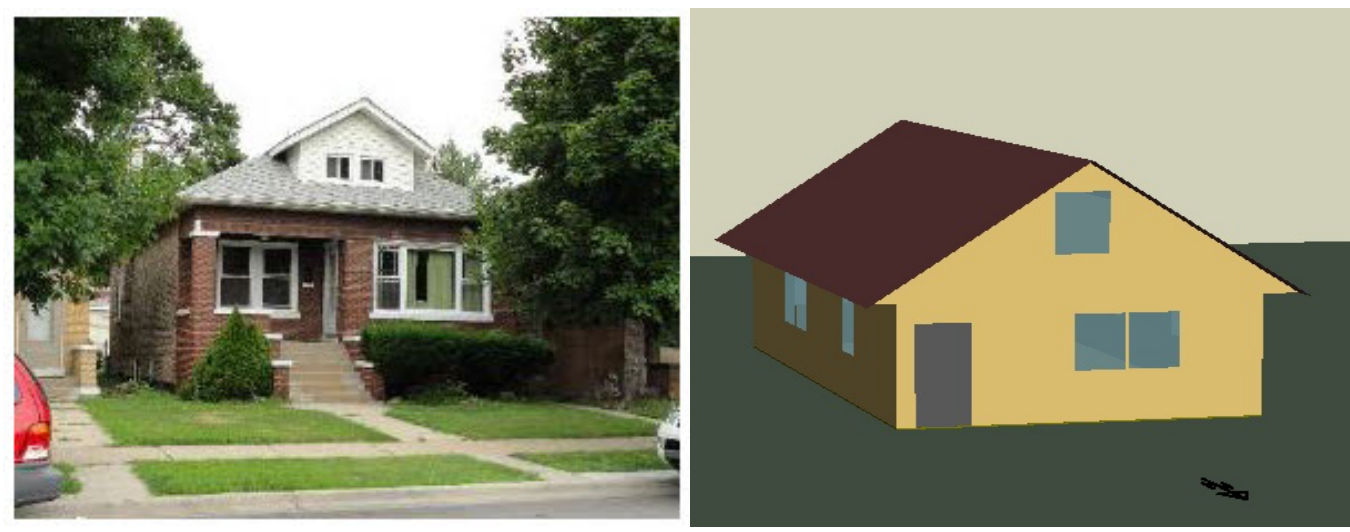

BEopt Results:

\begin{tabular}{|l|l|l|}
\hline Category & \multicolumn{1}{|c|}{ Today } & \multicolumn{1}{c|}{ Upgrade } \\
\hline Infiltration & Very Leaky & Leaky \\
\hline Unfinished Attic & $\begin{array}{l}\text { Ceiling R7 Fiberglass Blown-In, Vented; R19 } \\
\text { Fiberglass Roof Insulation }\end{array}$ & No change \\
\hline Furnace/Boiler & Gas, 80\% AFUE Boiler & Gas, 95\% AFUE Boiler \\
\hline Water Heater & Gas .54 EF & Gas Premium (0.67 EF) \\
\hline
\end{tabular}

Discussion:

For this pre-1942 bungalow-style house, the results were similar to the 1942-1978 bungalow above: infiltration upgraded one level, ceiling insulation unchanged due to the constraint in roof insulation and small area of ceiling insulation. In this case, all the equipment was upgraded. The boiler was likely upgraded because the walls are uninsulated and heating systems are a costeffective upgrade. Upgrading the water heater in this small house does not seem to be cost effective; PARR will investigate that upgrade further. 
Group 8: Brick, Pre-1942, 2 stories

Mean finished square footage: 1884

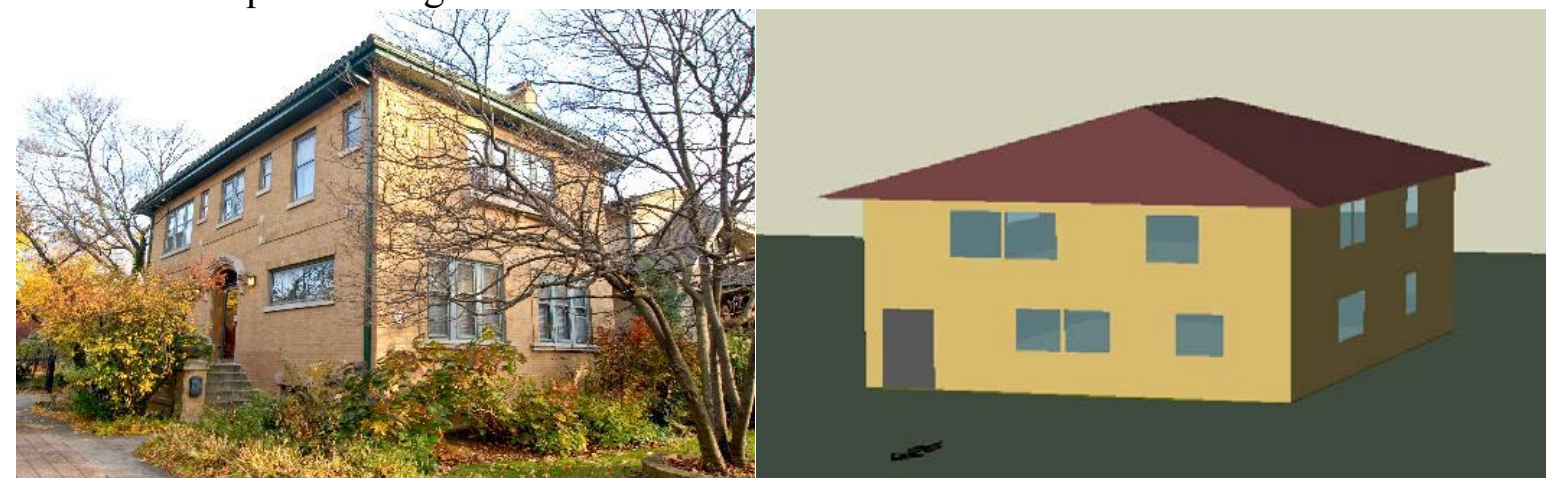

BEopt Results:

\begin{tabular}{|l|l|l|}
\hline Category & \multicolumn{1}{|c|}{ Today } & \multicolumn{1}{c|}{ Upgrade } \\
\hline Infiltration & Leaky & Typical \\
\hline Unfinished Attic & Ceiling R7 Fiberglass Blown-In, Vented & Ceiling R30 Fiberglass Blown-In, Vented \\
\hline Furnace/Boiler & Gas, 80\% AFUE Boiler & Gas, 95\% AFUE Boiler \\
\hline Water Heater & Gas .54 EF & Gas Premium (0.67 EF) \\
\hline
\end{tabular}

Discussion:

For this pre-1942 2 story, BEopt chose to upgrade all four categories. The infiltration upgraded one level because PARR believes a two-level upgrade is unreasonable and it was not modeled. The insulation was upgraded to R30 in this case instead of R38, possibly because of the poor performance of the insulation in the perimeter of the attic due to the low-slope roof. In this case, all the equipment was upgraded. The boiler was likely upgraded because the walls are uninsulated and heating systems are a cost-effective upgrade. Upgrading the water heater in this mid-size house may be cost effective due to the number of bedrooms.

Group 9: Frame, 1978-Present, 1 to 1.5 stories (no split level)

Mean finished square footage: 1801

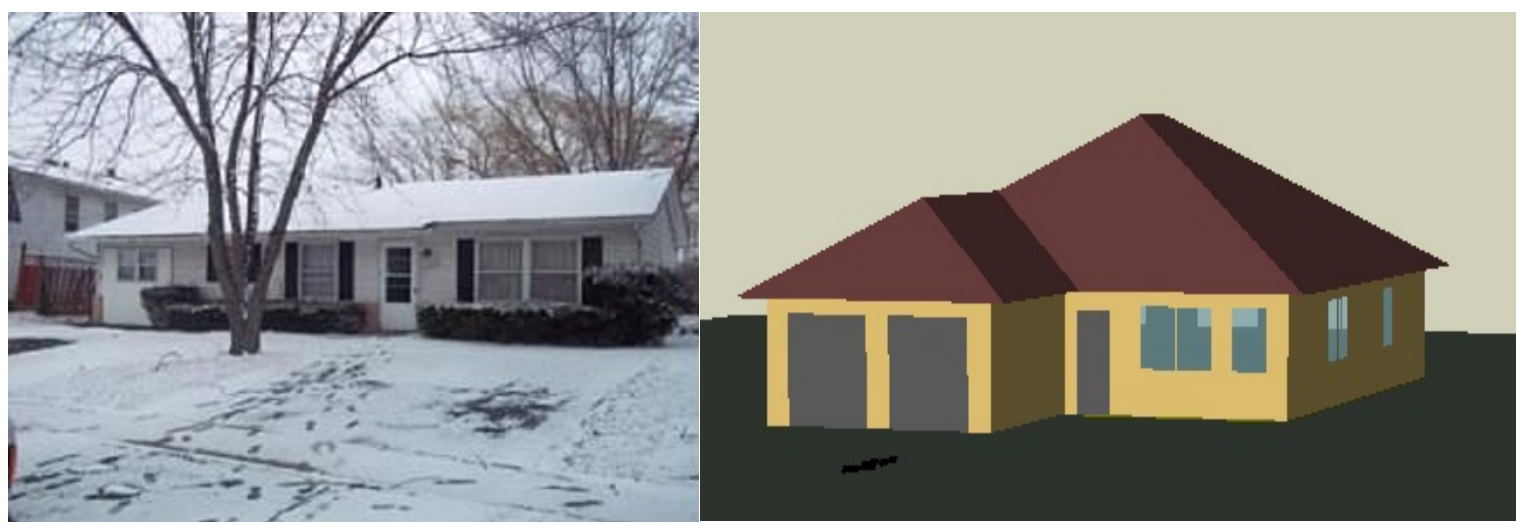


BEopt Results:

\begin{tabular}{|l|l|l|}
\hline Category & \multicolumn{1}{|c|}{ Today } & \multicolumn{1}{c|}{ Upgrade } \\
\hline Infiltration & Typical & No change \\
\hline Unfinished Attic & Ceiling R38 Fiberglass Batts, Vented & No change \\
\hline Furnace/Boiler & Gas, AFUE 78\% Furnace & Gas, AFUE 92.5\% Furnace \\
\hline Water Heater & Gas .54 EF & No change \\
\hline
\end{tabular}

Discussion:

For this post-1978 house, BEopt chose to upgrade only the furnace. The typical infiltration level may be suitable for this house. The ceiling insulation level at R38 is a common optimum level as in the other groups. Increasing the furnace efficiency may be cost effective because of the higher cost of insulating the large attic. The water heater was not upgraded in this case likely because of the cost of increasing the furnace in this recent vintage house.

Group 10: Frame, All years, Split level (1.5 stories)

Mean finished square footage: 1349
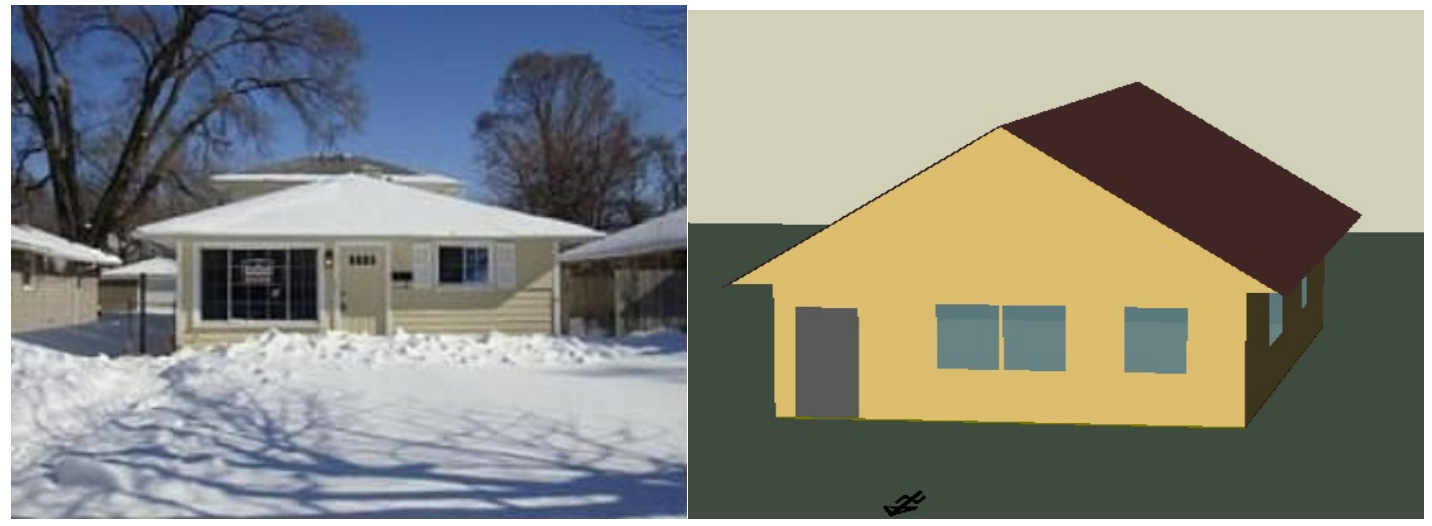

BEopt Results: (note - BEopt does not draw split level houses for drawing at right)

\begin{tabular}{|l|l|l|}
\hline Category & \multicolumn{1}{|c|}{ Today } & \multicolumn{1}{c|}{ Upgrade } \\
\hline Infiltration & Very Leaky & Leaky \\
\hline Unfinished Attic & $\begin{array}{l}\text { Ceiling R7 Fiberglass Blown-In, Vented } \\
\text { Roof R19 Fiberglass }\end{array}$ & $\begin{array}{l}\text { Ceiling R38 Fiberglass Blown-In, Vented } \\
\text { Roof R19 Fiberglass }\end{array}$ \\
\hline Furnace/Boiler & Gas, 80\% AFUE Boiler & Gas, 95\% AFUE Boiler \\
\hline Water Heater & Gas .54 EF & Gas Premium (0.67 EF) \\
\hline
\end{tabular}

Discussion:

Group 10 was modeled as a 1942 frame bungalow-style house because it best fit the EUI numbers from the field. Only the back half was modeled as a 1.5 story to match the split level description (note BEopt does not draw split-level houses). The results were similar to the 1942 Group 7 bungalow above, except the insulation level was increased: The infiltration upgraded one level as constrained by the modelers and the ceiling insulation was upgraded, likely due to the large ceiling area in the front of the house that had only R7 insulation on it. Again, in this 
case, all the equipment was upgraded. The boiler was likely upgraded because the walls are uninsulated and heating systems are a cost-effective upgrade. Upgrading the water heater in this small house does not seem to be cost effective; PARR will investigate that upgrade further.

Group 11: Frame, 1978-Present, 2 stories

Mean finished square footage: 3178
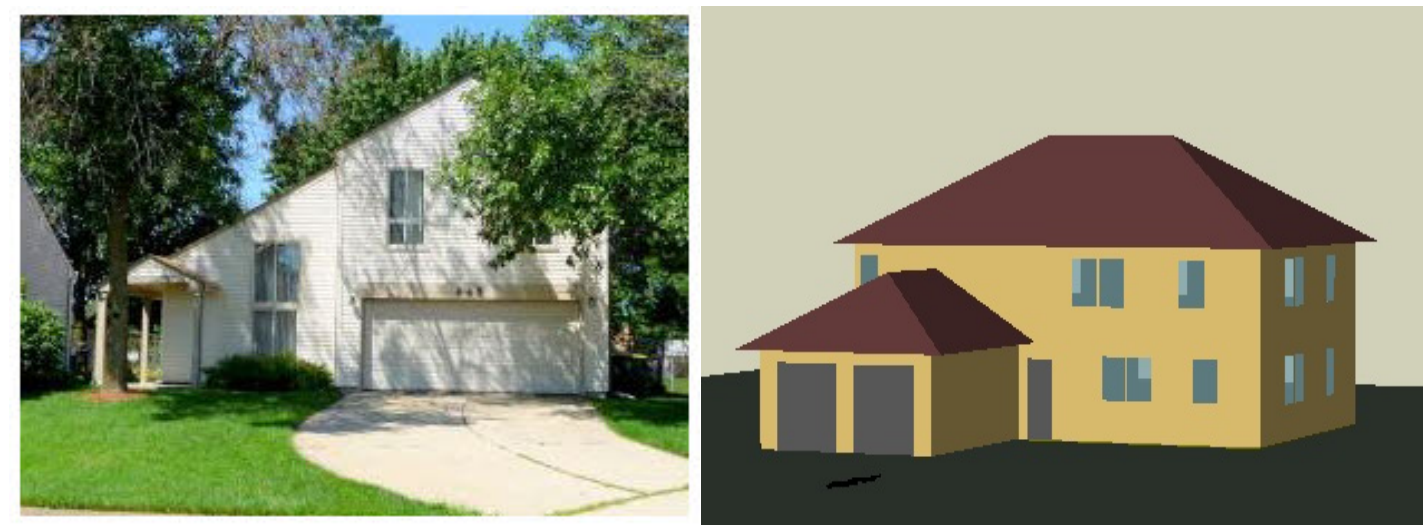

BEopt Results:

\begin{tabular}{|l|l|l|}
\hline Category & \multicolumn{1}{|c|}{ Today } & \multicolumn{1}{c|}{ Upgrade } \\
\hline Infiltration & Typical & Tight \\
\hline Unfinished Attic & Ceiling R38 Fiberglass Batts, Vented & No change \\
\hline Furnace/Boiler & Gas, AFUE 80\% Furnace & No change \\
\hline Water Heater & Gas .54 EF & Gas Premium $(0.67 \mathrm{EF})$ \\
\hline
\end{tabular}

Discussion:

Identical to Group 3, BEopt chose upgrading infiltration levels to tight because houses above 1 story best matched their EUI when modeled as typical and only a 1-level increase was permitted. Increasing attic insulation levels slightly was not cost effective likely because the R38 baseline was modeled. Increasing the furnace efficiency was not cost effective due to the good insulation level in the thermal envelope. Increasing the water heater EF may have been chosen because of the low cost of the infiltration upgrade. 


\section{Group 12: Frame, 1942-1978, 1 to 1.5 stories (no split level)}

Mean finished square footage: 1185
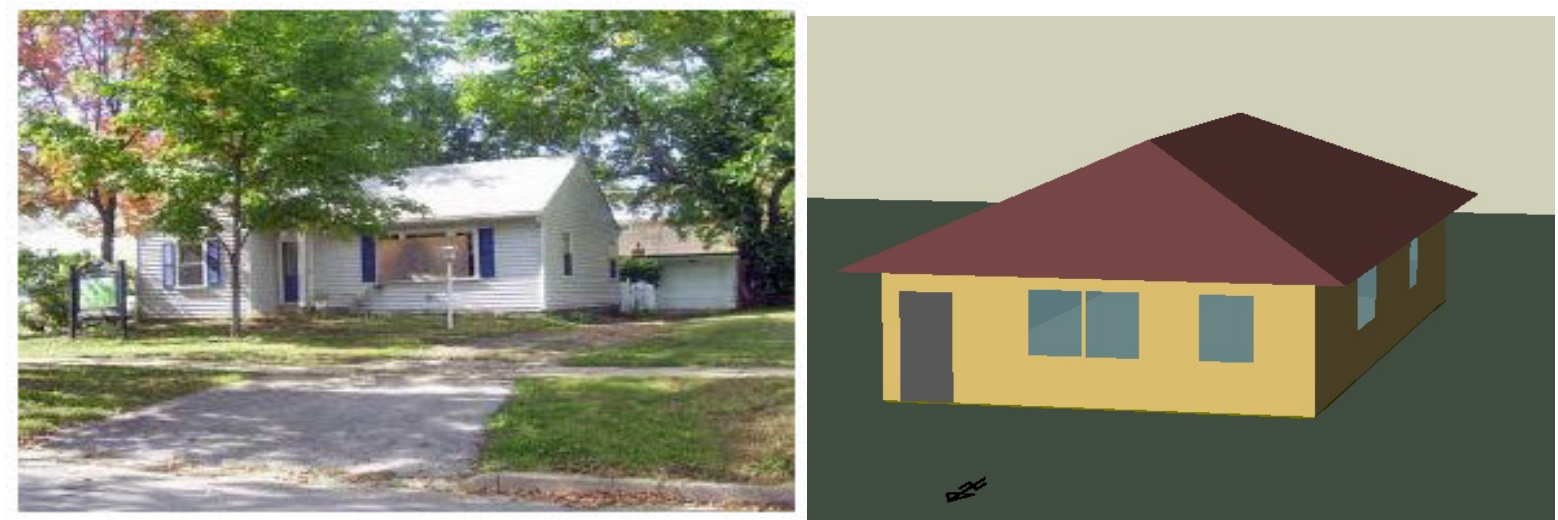

BEopt Results:

\begin{tabular}{|l|l|l|}
\hline Category & \multicolumn{1}{|c|}{ Today } & \multicolumn{1}{c|}{ Upgrade } \\
\hline Infiltration & Leaky & Typical \\
\hline Unfinished Attic & Ceiling R19 Fiberglass Blown-In, Vented & Ceiling R49 Fiberglass Blown-In, Vented \\
\hline Furnace/Boiler & Gas, AFUE 78\% Furnace & No change \\
\hline Water Heater & Gas .54 EF & No change \\
\hline
\end{tabular}

Discussion:

This 1942-1978 group was modeled as a single story to best match the EUI, unlike group 4 . BEopt chose upgrading infiltration levels one step to typical because a two-step upgrade was not considered realistic for this vintage and was not modeled. BEopt chose a higher level of attic insulation due to the large flat ceiling area and partially insulated walls. The furnace was not upgraded in this case likely due to the lower load for this smaller house with good attic insulation. The water heater was likely not upgraded due to the lower occupancy numbers with fewer bedrooms.

Group 13: Frame, 1942-1978, 2 stories

Mean finished square footage: 1586
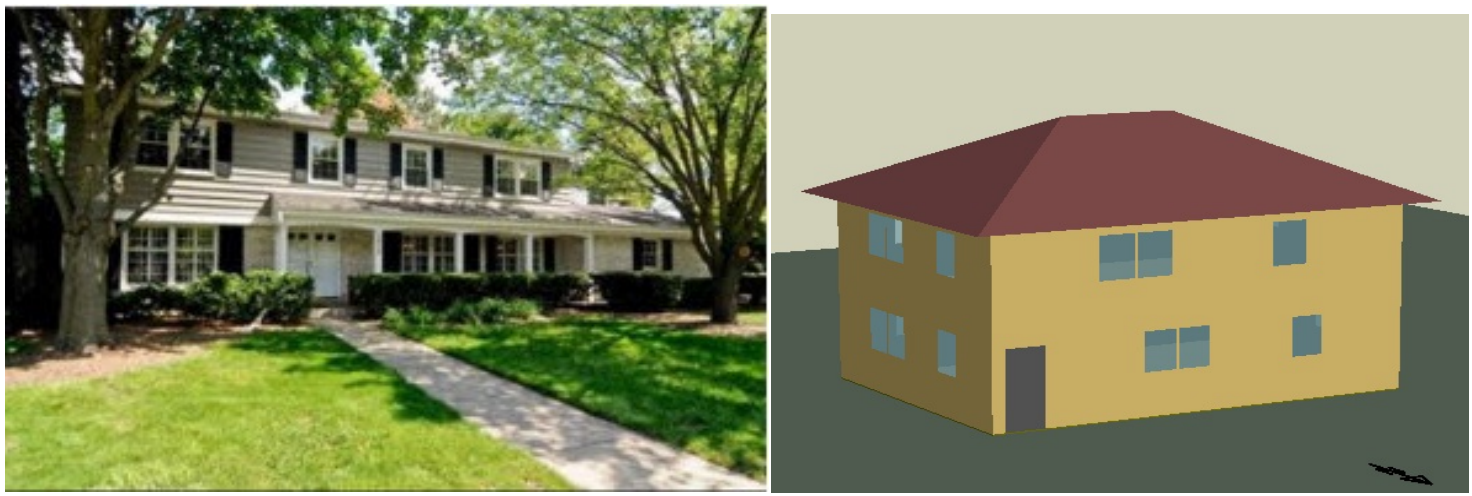
BEopt Results:

\begin{tabular}{|l|l|l|}
\hline Category & \multicolumn{1}{|c|}{ Today } & \multicolumn{1}{c|}{ Upgrade } \\
\hline Infiltration & Leaky & Typical \\
\hline Unfinished Attic & $\begin{array}{l}\text { Ceiling R11 Fiberglass Blown-In, } \\
\text { Vented }\end{array}$ & Ceiling R38 Fiberglass Blown-In, Vented \\
\hline Furnace/Boiler & Gas, AFUE 78\% Furnace & Gas, AFUE 92.5\% Furnace \\
\hline Water Heater & Gas .54 EF & No change \\
\hline
\end{tabular}

\section{Discussion:}

For this 1942-1978 2-story group, and unlike Group 6, BEopt upgraded all categories except the water heater. Infiltration was upgraded to typical as in most cases. Attic insulation was brought up to the R38 level as in many of the cases above. BEopt chose to increase the furnace efficiency in this case possibly due to the large thermal envelope area compared to the floor area of the house. The water heater was not upgraded in this case.

\section{Group 14: Frame, Pre-1942, 1 to 1.5 stories}

Mean finished square footage: 1254

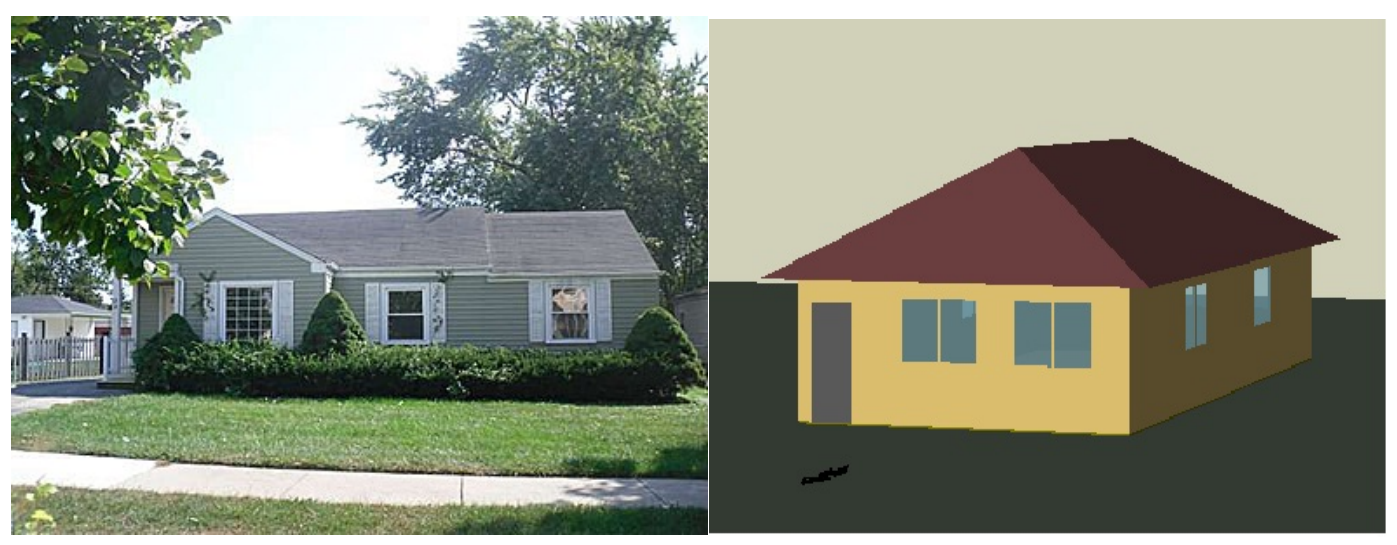

BEopt Results:

\begin{tabular}{|l|l|l|}
\hline Category & \multicolumn{1}{|c|}{ Today } & \multicolumn{1}{c|}{ Upgrade } \\
\hline Infiltration & Very Leaky & Leaky \\
\hline Unfinished Attic & Floored R3 roof insulation unvented & Ceiling R38 Fiberglass Blown-In, Vented \\
\hline Furnace/Boiler & Gas, 80\% AFUE Boiler & Gas, 95\% AFUE Boiler \\
\hline Water Heater & Gas .54 EF & Gas Premium (0.67 EF) \\
\hline
\end{tabular}

Discussion:

For this pre-1942 1-story house, infiltration was upgraded one level and ceiling insulation was increased due to the large flat mostly uninsulated ceiling. In this case, all the equipment was upgraded. The boiler was likely upgraded because the walls are uninsulated and heating systems are a cost-effective upgrade. Upgrading the water heater in this small house may be cost effective because wall insulation was not considered. 
Group 15: Frame, Pre-1942, 2 stories

Mean finished square footage: 2058

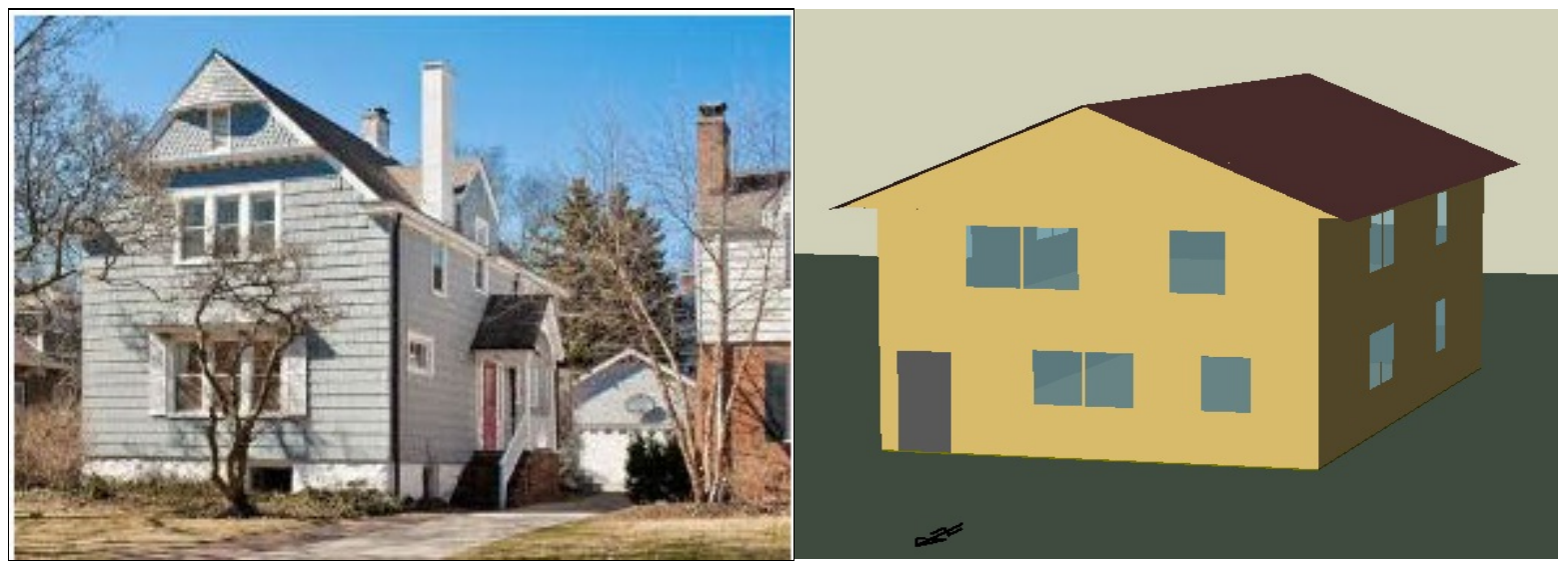

BEopt Results:

\begin{tabular}{|l|l|l|}
\hline Category & \multicolumn{1}{|c|}{ Today } & \multicolumn{1}{c|}{ Upgrade } \\
\hline Infiltration & Leaky & Typical \\
\hline Unfinished Attic & $\begin{array}{l}\text { Ceiling R7 Fiberglass Blown-In, } \\
\text { Vented }\end{array}$ & Ceiling R38 Fiberglass Blown-In, Vented \\
\hline Furnace/Boiler & Gas, 80\% AFUE Boiler & Gas, 95\% AFUE Boiler \\
\hline Water Heater & Gas .54 EF & Gas Premium (0.67 EF) \\
\hline
\end{tabular}

Discussion:

For this pre-1942 2 story, as in Group 8, BEopt chose to upgrade all four categories. The infiltration upgraded one level because PARR believes a two-level upgrade is unreasonable and it was not modeled. The insulation was upgraded to R38 in this case instead of R30, possibly because of the better performance of the insulation in the perimeter of the attic due to the hip roof design. In this case, all the equipment was upgraded. The boiler was likely upgraded because the walls are uninsulated and heating systems are a cost-effective upgrade. Upgrading the water heater in this mid-size house may be cost effective due to the number of bedrooms.

\subsection{Analysis}

The potential source energy reduction for each group was calculated using BEopt output reports for gas and electric site energy reduction and converting the values to source energy using multipliers for Chicago. Table 12, below, provides the percentage source energy reduction by group and then ranked to identify the highest percentage reduction. Appendix III contains detailed tables and graphs showing energy savings in therms, source EUI, and $\mathrm{kWh}$.

The top Source EUI energy-savings percentage by group are groups 14, 15, and 8 representing the Pre-1942 frame bungalow, pre-1942 frame 2 story, and the pre-1942 brick 2-story houses. This analysis reflects the first two criteria needed to determine the target groups for retrofit. 
Table 12. Source EUI Reduction Percentage by Group

\begin{tabular}{|r|r|r|}
\hline Group & Source EUI Reduction, $\mathbf{\%}^{\mathbf{5}}$ & Rank \\
\hline $\mathbf{1 4}$ & $28 \%$ & 1 \\
$\mathbf{1 5}$ & $22 \%$ & 2 \\
$\mathbf{8}$ & $20 \%$ & 3 \\
\hline $\mathbf{1 0}$ & $19 \%$ & 4 \\
\hline $\mathbf{7}$ & $19 \%$ & 5 \\
\hline $\mathbf{6}$ & $11 \%$ & 6 \\
\hline $\mathbf{1 2}$ & $11 \%$ & 7 \\
\hline $\mathbf{1 3}$ & $11 \%$ & 8 \\
\hline $\mathbf{1 1}$ & $9 \%$ & 9 \\
\hline $\mathbf{5}$ & $9 \%$ & 10 \\
\hline $\mathbf{3}$ & $9 \%$ & 11 \\
\hline $\mathbf{4}$ & $8 \%$ & 12 \\
\hline $\mathbf{2}$ & $\mathbf{7} \%$ & 13 \\
\hline $\mathbf{9}$ & $6 \%$ & 14 \\
\hline $\mathbf{1}$ & $5 \%$ & 15 \\
\hline & & \\
\hline
\end{tabular}

The third criteria applies the optimal energy saving to the number of homes in a group and then by size of the home to arrive at an annual savings potential in millions of Btu for each group. Table 13, below provides the final rank by group using that metric.

Table 13. Final Rank by Group

\begin{tabular}{|r|r|r|r|r|}
\hline Group & Number of homes & $\begin{array}{c}\text { Source EUI } \\
\text { Savings \% }\end{array}$ & $\begin{array}{c}\text { Total Source } \\
\text { Energy Savings } \\
\text { (million Btu) }\end{array}$ & Rank \\
\hline $\mathbf{1 4}$ & 48365 & $28 \%$ & $3,718,320$ & 1 \\
\hline $\mathbf{1 2}$ & 101957 & $11 \%$ & $2,471,892$ & 2 \\
\hline $\mathbf{7}$ & 50239 & $19 \%$ & $2,409,359$ & 3 \\
\hline $\mathbf{4}$ & 77435 & $8 \%$ & $1,369,018$ & 4 \\
\hline $\mathbf{8}$ & 17629 & $20 \%$ & $1,179,926$ & 6 \\
\hline $\mathbf{1 5}$ & 12479 & $22 \%$ & 950,418 & 7 \\
\hline $\mathbf{6}$ & 20755 & $11 \%$ & 738,176 & 8 \\
\hline $\mathbf{5}$ & 26445 & $9 \%$ & 638,185 & 10 \\
\hline $\mathbf{3}$ & 20530 & $9 \%$ & 535,369 & 11 \\
\hline $\mathbf{1 3}$ & 16411 & $11 \%$ & 474,008 & 12 \\
\hline $\mathbf{1 0}$ & 9225 & $19 \%$ & 445,641 & 13 \\
\hline $\mathbf{1 1}$ & 4544 & $9 \%$ & 140,783 & 132,042 \\
\hline $\mathbf{1}$ & 10856 & $5 \%$ & & \\
\hline
\end{tabular}

\footnotetext{
${ }^{5}$ For later discussion: BEopt does not identify any cost-effective retrofit packages that will lead to $30 \%$ source savings.
} 


\begin{tabular}{|r|r|r|r|r|}
\hline Group & Number of homes & $\begin{array}{c}\text { Source EUI } \\
\text { Savings \% }\end{array}$ & $\begin{array}{c}\text { Total Source } \\
\text { Energy Savings } \\
\text { (million Btu) }\end{array}$ & Rank \\
\hline $\mathbf{2}$ & 8417 & $7 \%$ & 130,548 & 14 \\
\hline $\mathbf{9}$ & 7318 & $6 \%$ & 99,835 & 15 \\
\hline
\end{tabular}

The result of the analysis then identifies the following groups as the top three groups in the Chicagoland area for retrofit:

1) Group 14: Frame, Pre-1942, 1 to 1.5 stories

2) Group 12: Frame, 1942-1978, 1 to 1.5 stories

3) Group 7: Brick, Pre-1942, 1 to 1.5 stories

These three groups include $46 \%$ of the housing stock in Cook County, and represent the potential for over 100 million therms of source energy savings per year ${ }^{6}$.

\section{Conclusions}

In this study, PARR identified 15 groups that cluster the Cook County, Illinois, single-family detached houses by vintage, construction detail, and energy use intensity. The team further characterized each group using assessor data and utility energy billing data, and used this data to build three BEopt cases for each group: As-built, Today, and with Upgrade using the most costeffective measures. The BEopt analysis predicts significant energy savings in three 1 to 1.5 story groups: pre-1942 brick, pre-1942 frame, and 1942-1978 brick construction. The groups save $28 \%, 19 \%$, and $11 \%$ of source energy respectively, and because of the large number of these houses across the geographic area, they represent the first, second, and third largest energy saving potential by housing type. PARR identifies these three groups as those best matching the criteria set forth in this study.

Next year, PARR will take these results into the field to improve the assumptions used, validate the model, gather data on the actual upgrades between the As-built and Today cases, and develop a better retrofit cost database for these buildings. PARR also expects to explore the cost effectiveness of additional measures that could be used to achieve the $30 \%$ energy savings target for these homes, and to better define and document the costs and measured savings of singlefamily home retrofits. This will help: (1) increase visibility of the measures to energy efficiency portfolios of utility companies, (2) provide achievable savings predictions based on home type to single-family homeowners who are interested in cost-effective measures, and (3) create the most cost-effective retrofit package to market to those homeowners.

The following research questions were addressed in this project:

What are the most common housing types in Cook County? Fifteen groups were identified and their populations are presented in this report.

What are the energy use characteristics of these housing types? Source and site energy use for each group are provided in this report.

\footnotetext{
${ }^{6}$ If every home in Cook County that is a part of the top three groups were to be retrofitted.
} 
Can large datasets be used to identify cost-effective retrofit opportunities? PARR was successful in segmenting nearly 500,000 buildings into 15 groups and identifying retrofit opportunities.

What are the types of housing to target for retrofit packages? This topic is covered in some depth in the Analysis section.

Do identified databases provide sufficient detail for modeling inputs? PARR was able to model the 15 groups to within $10 \%$ of measured EUI by making reasonable assumptions regarding construction characteristics and upgrades since construction.

\section{What housing characteristics are most significant toward determining cost} effectiveness of retrofit? Through statistical analysis and three clustering techniques, the characteristics in the CNT Energy dataset found to be most significant are the home vintage, construction type, and size.

What is the relationship between housing type energy intensity and potential costeffective energy savings? PARR identified that the higher energy-intensive structures were the best opportunity for upgrade, but factoring in the cost to upgrade and the size of the population provided target groups that were not always the most energy intensive or the most cost effective. The outcome of this study is a methodology to customize prescriptive retrofit packages to distinct housing groups at scale.

Although the housing types presented here and the retrofit packages presented are specific to the cold climate of northern Illinois, the segmentation methodology presented in this report is intended to be replicable elsewhere. This approach can have dramatic impact on how broad-scale retrofit implementation programs are developed, implemented and brought to scale. 


\section{References}

Cook County Assessor. http://cookcountyassessor.com/

ICC (2012). International Energy Conservation Code. Washington, D.C. International Code Council.

Kalensky, D. (2012) AHRI Furnace Shipments by Efficiency (internal GTI memorandum)

Kelso, J., (2003). U. S. Department of Energy. Incorporating Water Heater Replacement into the Weatherization Assistance Program, An Information Toolkit

LBNL Study on Appliance Efficiency Standards. http://ees.ead.lbl.gov/node/2

U. S. Bureau of the Census. http://www.census.gov/

U. S. Department of Energy. (2008). History of Federal Appliance Standards. Accessed March 2012: http://www1.eere.energy.gov/buildings/appliance standards/history.html.

Zimring et al. (2011) "Delivering Energy Efficiency to Middle Income Single Family Households.” Environmental Energy Technologies Division, Lawrence Berkeley National Laboratory. 


\section{Appendix I - Detail on Housing Group Characteristics}

This appendix provides the detail on housing group characteristics that were used for the basis of developing the 15 groups and then carried forward into the BEopt modeling assumptions.

\begin{tabular}{|l|l|l|l|}
\hline GROUP & Construction & Year & Stories \\
\hline $\mathbf{1}$ & Brick & 1978-Present & 1 to 1.5 (no split level) \\
\hline $\mathbf{2}$ & Brick & $1978-$ Present & 1.5 - split level \\
\hline $\mathbf{3}$ & Brick & $1978-$ Present & 2 \\
\hline $\mathbf{4}$ & Brick & $1942-1978$ & 1 to 1.5 (no split level) \\
\hline $\mathbf{5}$ & Brick & Pre-1978 & 1.5 - split level \\
\hline $\mathbf{6}$ & Brick & $1942-1978$ & 2 \\
\hline $\mathbf{7}$ & Brick & Pre-1942 & 1 to 1.5 (no split level) \\
\hline $\mathbf{8}$ & Brick & Pre-1942 & 2 \\
\hline $\mathbf{9}$ & Frame & $1978-P r e s e n t$ & 1 to 1.5 (no split level) \\
\hline $\mathbf{1 0}$ & Frame & All & $1.5-$ split level \\
\hline $\mathbf{1 1}$ & Frame & $1978-P r e s e n t$ & 2 \\
\hline $\mathbf{1 2}$ & Frame & $1942-1978$ & 1 to 1.5 (no split level) \\
\hline $\mathbf{1 3}$ & Frame & $1942-1978$ & 2 \\
\hline $\mathbf{1 4}$ & Frame & Pre-1942 & 1 to 1.5 (no split level) \\
\hline $\mathbf{1 5}$ & Frame & Pre-1942 & 2 \\
\hline
\end{tabular}

\begin{tabular}{|l|l|l|l|l|l|}
\hline & & \multicolumn{5}{|l|}{ Square Footage } \\
\hline GROUP & N Obs & \% of Population & Mean & Std Dev & Median \\
\hline $\mathbf{1}$ & 10856 & $2.5 \%$ & 1741 & 474 & 1720 \\
\hline $\mathbf{2}$ & 8417 & $1.9 \%$ & 1404 & 264 & 1368 \\
\hline $\mathbf{3}$ & 20530 & $4.7 \%$ & 2506 & 673 & 2425 \\
\hline $\mathbf{4}$ & 77435 & $17.9 \%$ & 1217 & 354 & 1136 \\
\hline $\mathbf{5}$ & 26445 & $6.1 \%$ & 1299 & 274 & 1256 \\
\hline $\mathbf{6}$ & 20755 & $4.8 \%$ & 2059 & 620 & 1987 \\
\hline $\mathbf{7}$ & 50239 & $11.6 \%$ & 1141 & 360 & 1072 \\
\hline $\mathbf{8}$ & 17629 & $4.1 \%$ & 1884 & 549 & 1784 \\
\hline $\mathbf{9}$ & 7318 & $1.7 \%$ & 1801 & 637 & 1641 \\
\hline $\mathbf{1 0}$ & 9225 & $2.1 \%$ & 1349 & 282 & 1303 \\
\hline $\mathbf{1 1}$ & 4544 & $1.1 \%$ & 3178 & 909 & 3146 \\
\hline $\mathbf{1 2}$ & 101957 & $23.6 \%$ & 1185 & 301 & 1114 \\
\hline $\mathbf{1 3}$ & 16411 & $3.8 \%$ & 1586 & 565 & 1427 \\
\hline $\mathbf{1 4}$ & 48365 & $11.2 \%$ & 1254 & 357 & 1176 \\
\hline $\mathbf{1 5}$ & 12479 & $2.9 \%$ & 2058 & 624 & 1962 \\
\hline
\end{tabular}




\begin{tabular}{|l|l|l|l|l|l|l|}
\hline \multicolumn{5}{|l|}{ Year built } & \multicolumn{3}{l|}{ Site EUI } \\
\hline GROUP & Mean & Std Dev & Median & Mean & Std Dev & Median \\
\hline $\mathbf{1}$ & 1991 & 7 & 1990 & 81.8 & 25 & 78.4 \\
\hline $\mathbf{2}$ & 1987 & 6 & 1987 & 112.6 & 26.2 & 109.9 \\
\hline $\mathbf{3}$ & 1992 & 7 & 1993 & 76.7 & 18.3 & 74.5 \\
\hline $\mathbf{4}$ & 1959 & 8 & 1958 & 129.6 & 39.8 & 123.7 \\
\hline $\mathbf{5}$ & 1968 & 6 & 1968 & 131.5 & 33.4 & 127.2 \\
\hline $\mathbf{6}$ & 1962 & 11 & 1964 & 99.8 & 29.7 & 94.5 \\
\hline $\mathbf{7}$ & 1917 & 14 & 1921 & 161.3 & 49.2 & 157.1 \\
\hline $\mathbf{8}$ & 1911 & 16 & 1910 & 117.3 & 32.4 & 113.6 \\
\hline $\mathbf{9}$ & 1992 & 8 & 1991 & 91.8 & 32.4 & 85.5 \\
\hline $\mathbf{1 0}$ & 1966 & 8 & 1964 & 136.6 & 35.1 & 132.7 \\
\hline $\mathbf{1 1}$ & 1996 & 6 & 1998 & 73.8 & 20.7 & 70.4 \\
\hline $\mathbf{1 2}$ & 1958 & 7 & 1958 & 135.3 & 37.7 & 131.4 \\
\hline $\mathbf{1 3}$ & 1951 & 7 & 1950 & 119.2 & 31.8 & 116.4 \\
\hline $\mathbf{1 4}$ & 1924 & 10 & 1926 & 158.9 & 44.6 & 156.2 \\
\hline $\mathbf{1 5}$ & 1922 & 14 & 1923 & 116 & 30.1 & 112.8 \\
\hline
\end{tabular}

\begin{tabular}{|c|c|c|c|c|c|c|}
\hline \multirow[b]{2}{*}{ GROUP } & \multicolumn{3}{|c|}{ Therms } & \multicolumn{3}{|l|}{ kWh } \\
\hline & Mean & Std Dev & Median & Mean & Std Dev & Median \\
\hline 1 & 1077 & 351 & 1033 & 8887 & 4097 & 8122 \\
\hline 2 & 1205 & 276 & 1174 & 10076 & 3771 & 9547 \\
\hline 3 & 1446 & 406 & 1393 & 12482 & 4914 & 11721 \\
\hline 4 & 1212 & 379 & 1161 & 8859 & 4065 & 8189 \\
\hline 5 & 1344 & 360 & 1298 & 9643 & 3922 & 9041 \\
\hline 6 & 1553 & 435 & 1499 & 11714 & 5003 & 10960 \\
\hline 7 & 1442 & 433 & 1400 & 8927 & 4382 & 8265 \\
\hline 8 & 1757 & 525 & 1696 & 11062 & 5213 & 10214 \\
\hline 9 & 1217 & 409 & 1171 & 9719 & 4454 & 8903 \\
\hline 10 & 1480 & 372 & 1449 & 9321 & 3860 & 8733 \\
\hline 11 & 1749 & 502 & 1681 & 14914 & 5678 & 14209 \\
\hline 12 & 1268 & 356 & 1228 & 8483 & 3910 & 7858 \\
\hline 13 & 1467 & 424 & 1406 & 9802 & 4653 & 8952 \\
\hline 14 & 1608 & 445 & 1570 & 9050 & 4463 & 8337 \\
\hline 15 & 1913 & 549 & 1857 & 11348 & 5374 & 10460 \\
\hline
\end{tabular}




\begin{tabular}{|l|l|l|l|l|l|l|l|l|}
\hline & $\begin{array}{l}\text { Central } \\
\text { Gas } \\
\text { Furnace }\end{array}$ & $\begin{array}{l}\text { Central } \\
\text { Gas } \\
\text { Furnace }\end{array}$ & $\begin{array}{l}\text { Gas } \\
\text { Boiler }\end{array}$ & $\begin{array}{l}\text { Gas } \\
\text { Boiler }\end{array}$ & CentralAC & CentralAC & $\begin{array}{l}\text { Window } \\
\text { AC or } \\
\text { None }\end{array}$ & $\begin{array}{l}\text { Window } \\
\text { AC or } \\
\text { None }\end{array}$ \\
\hline GROUP & $\mathbf{n}$ & $\mathbf{\%}$ & $\mathbf{n}$ & $\mathbf{\%}$ & $\mathbf{n}$ & $\mathbf{\%}$ & $\mathbf{n}$ & $\mathbf{\%}$ \\
\hline $\mathbf{1}$ & 10836 & $99.82 \%$ & 20 & $0.18 \%$ & 9401 & $86.60 \%$ & 1455 & $13.40 \%$ \\
\hline $\mathbf{2}$ & 8413 & $99.95 \%$ & 4 & $0.05 \%$ & 6345 & $75.38 \%$ & 2072 & $24.62 \%$ \\
\hline $\mathbf{3}$ & 20514 & $99.92 \%$ & 16 & $0.08 \%$ & 18375 & $89.50 \%$ & 2155 & $10.50 \%$ \\
\hline $\mathbf{4}$ & 73861 & $95.38 \%$ & 3574 & $4.62 \%$ & 27032 & $34.91 \%$ & 50403 & $65.09 \%$ \\
\hline $\mathbf{5}$ & 25504 & $96.44 \%$ & 941 & $3.56 \%$ & 14745 & $55.76 \%$ & 11700 & $44.24 \%$ \\
\hline $\mathbf{6}$ & 19794 & $95.37 \%$ & 961 & $4.63 \%$ & 12982 & $62.55 \%$ & 7773 & $37.45 \%$ \\
\hline $\mathbf{7}$ & 39810 & $79.24 \%$ & 10429 & $20.76 \%$ & 5342 & $10.63 \%$ & 44897 & $89.37 \%$ \\
\hline $\mathbf{8}$ & 11696 & $66.35 \%$ & 5933 & $33.65 \%$ & 3800 & $21.56 \%$ & 13829 & $78.44 \%$ \\
\hline $\mathbf{9}$ & 7295 & $99.69 \%$ & 23 & $0.31 \%$ & 6078 & $83.06 \%$ & 1240 & $16.94 \%$ \\
\hline $\mathbf{1 0}$ & 8505 & $92.20 \%$ & 720 & $7.80 \%$ & 5528 & $59.92 \%$ & 3697 & $40.08 \%$ \\
\hline $\mathbf{1 1}$ & 4529 & $99.67 \%$ & 15 & $0.33 \%$ & 4343 & $95.58 \%$ & 201 & $4.42 \%$ \\
\hline $\mathbf{1 2}$ & 95745 & $93.91 \%$ & 6212 & $6.09 \%$ & 43400 & $42.57 \%$ & 58557 & $57.43 \%$ \\
\hline $\mathbf{1 3}$ & 15511 & $94.52 \%$ & 900 & $5.48 \%$ & 6989 & $42.59 \%$ & 9422 & $57.41 \%$ \\
\hline $\mathbf{1 4}$ & 25459 & $52.64 \%$ & 22906 & $47.36 \%$ & 5147 & $10.64 \%$ & 43218 & $89.36 \%$ \\
\hline $\mathbf{1 5}$ & 5993 & $48.02 \%$ & 6486 & $51.98 \%$ & 2867 & $22.97 \%$ & 9612 & $77.03 \%$ \\
\hline
\end{tabular}

\begin{tabular}{|l|l|l|l|l|l|l|l|}
\hline GROUP & Attic Description & $\begin{array}{l}\text { Full and } \\
\text { Apartment }\end{array}$ & $\begin{array}{l}\text { Full and Living } \\
\text { Area }\end{array}$ & $\begin{array}{l}\text { None } \\
\text { Unfinished }\end{array}$ & $\begin{array}{l}\text { Partial } \\
\text { \&Living } \\
\text { Area }\end{array}$ & $\begin{array}{l}\text { Partial and } \\
\text { Unfinished }\end{array}$ & Total \\
\hline $\mathbf{1}$ & 0 & 385 & 93 & 9679 & 454 & 222 & 10833 \\
\hline $\mathbf{2}$ & 0 & 9 & 15 & 8254 & 16 & 79 & 8373 \\
\hline $\mathbf{3}$ & 0 & 79 & 305 & 19015 & 477 & 581 & 20457 \\
\hline $\mathbf{4}$ & 0 & 6488 & 5799 & 52727 & 2652 & 9469 & 77135 \\
\hline $\mathbf{5}$ & 0 & 27 & 444 & 22625 & 106 & 3190 & 26392 \\
\hline $\mathbf{6}$ & 0 & 222 & 767 & 17321 & 302 & 2080 & 20692 \\
\hline $\mathbf{7}$ & 7 & 13549 & 8843 & 19160 & 3212 & 5188 & 49959 \\
\hline $\mathbf{8}$ & 3 & 1117 & 3331 & 8615 & 832 & 3620 & 17518 \\
\hline $\mathbf{9}$ & 0 & 132 & 55 & 6725 & 181 & 210 & 7303 \\
\hline $\mathbf{1 0}$ & 0 & 20 & 150 & 7934 & 52 & 1039 & 9195 \\
\hline $\mathbf{1 1}$ & 0 & 39 & 101 & 4020 & 141 & 232 & 4533 \\
\hline $\mathbf{1 2}$ & 0 & 8585 & 11280 & 68057 & 2028 & 11641 & 101591 \\
\hline $\mathbf{1 3}$ & 0 & 150 & 972 & 13060 & 126 & 2055 & 16363 \\
\hline $\mathbf{1 4}$ & 4 & 10277 & 17722 & 10484 & 3189 & 6564 & 48240 \\
\hline $\mathbf{1 5}$ & 0 & 680 & 2192 & 6387 & 541 & 2627 & 12427 \\
\hline
\end{tabular}




\begin{tabular}{|l|l|l|l|l|l|l|l|l|l|}
\hline GROUP & \multicolumn{9}{|l|}{ Basement Description } \\
\hline & Crawl & $\begin{array}{l}\text { Full and } \\
\text { Apartment }\end{array}$ & $\begin{array}{l}\text { Full and } \\
\text { Rec } \\
\text { Room }\end{array}$ & $\begin{array}{l}\text { Full } \\
\text { and } \\
\text { Unfin- } \\
\text { ished }\end{array}$ & $\begin{array}{l}\text { Partial } \\
\text { and } \\
\text { Apartment }\end{array}$ & $\begin{array}{l}\text { Partial } \\
\text { and } \\
\text { Rec } \\
\text { Room }\end{array}$ & $\begin{array}{l}\text { Partial } \\
\text { and } \\
\text { Unfinished }\end{array}$ & Slab & Total \\
\hline $\mathbf{1}$ & 687 & 0 & 677 & 3756 & 0 & 712 & 2229 & 2772 & 10833 \\
\hline $\mathbf{2}$ & 42 & 0 & 396 & 22 & 0 & 7707 & 183 & 23 & 8373 \\
\hline $\mathbf{3}$ & 628 & 0 & 1484 & 11021 & 0 & 817 & 5267 & 1240 & 20457 \\
\hline $\mathbf{4}$ & 11430 & 1 & 10330 & 18637 & 0 & 5378 & 6839 & 24520 & 77135 \\
\hline $\mathbf{5}$ & 46 & 0 & 734 & 85 & 0 & 25205 & 247 & 75 & 26392 \\
\hline $\mathbf{6}$ & 1311 & 0 & 2105 & 5093 & 0 & 3175 & 4755 & 4253 & 20692 \\
\hline $\mathbf{7}$ & 1143 & 8 & 7548 & 27062 & 1 & 759 & 2305 & 11133 & 49959 \\
\hline $\mathbf{8}$ & 261 & 0 & 2315 & 11279 & 0 & 421 & 1431 & 1811 & 17518 \\
\hline $\mathbf{9}$ & 159 & 0 & 1063 & 3587 & 0 & 309 & 1016 & 1169 & 7303 \\
\hline $\mathbf{1 0}$ & 9 & 0 & 437 & 27 & 0 & 8620 & 94 & 8 & 9195 \\
\hline $\mathbf{1 1}$ & 38 & 1 & 851 & 2837 & 0 & 196 & 501 & 109 & 4533 \\
\hline $\mathbf{1 2}$ & 4264 & 3 & 26130 & 59221 & 0 & 2607 & 4195 & 5171 & 101591 \\
\hline $\mathbf{1 3}$ & 188 & 0 & 4972 & 8567 & 0 & 979 & 1194 & 463 & 16363 \\
\hline $\mathbf{1 4}$ & 206 & 4 & 10890 & 34490 & 1 & 635 & 858 & 1156 & 48240 \\
\hline $\mathbf{1 5}$ & 47 & 0 & 2598 & 8381 & 0 & 374 & 828 & 199 & 12427 \\
\hline
\end{tabular}




\section{Appendix II - BEopt Modeling Assumptions Tables}

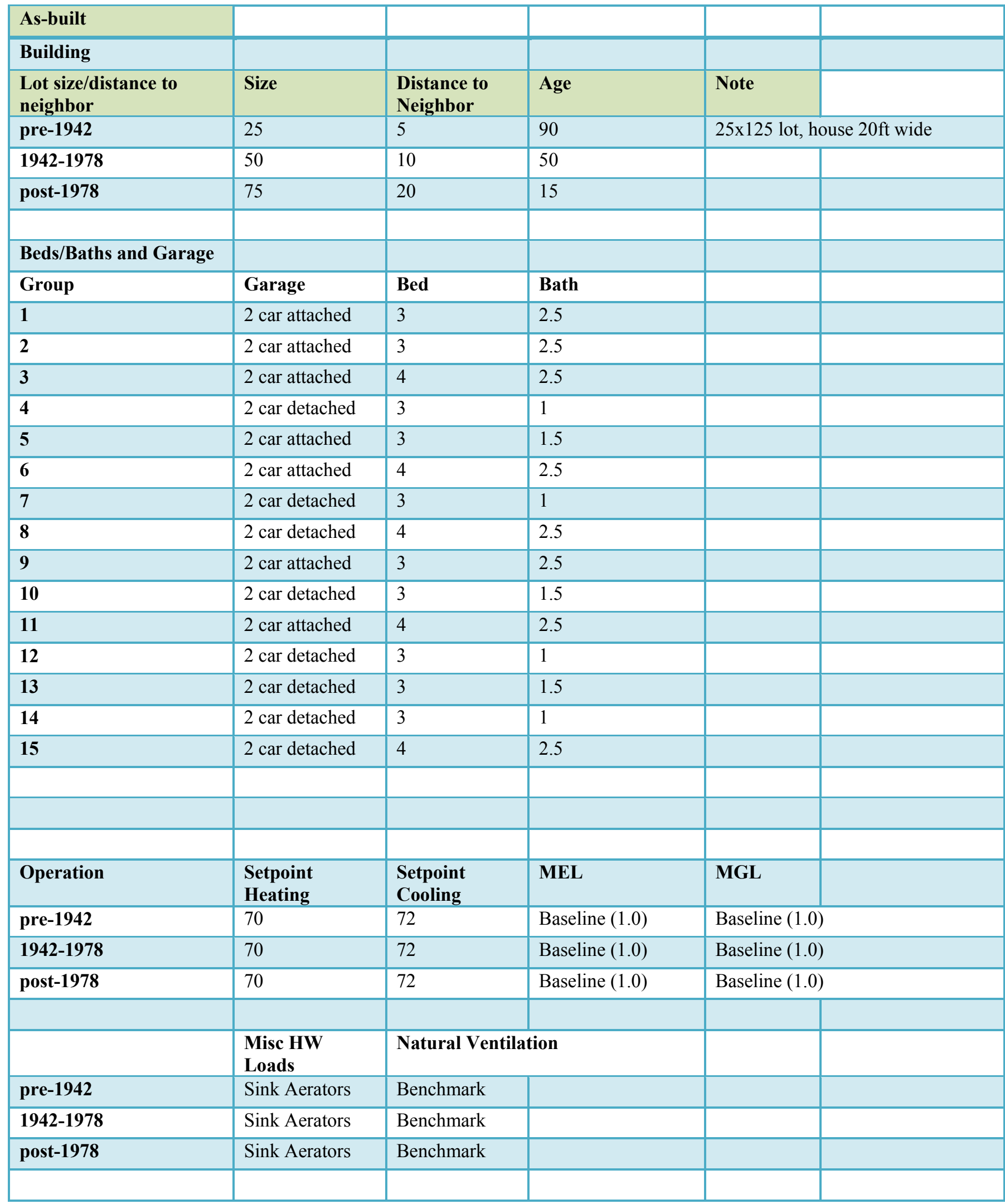




\begin{tabular}{|c|c|c|c|c|c|}
\hline \multicolumn{6}{|l|}{ As-built } \\
\hline \multicolumn{6}{|l|}{ Walls/Ceilings/Roofs } \\
\hline Brick & $\begin{array}{l}\text { (outside to } \\
\text { inside) }\end{array}$ & & & & \\
\hline \multicolumn{6}{|l|}{ Wall construction } \\
\hline pre-1942 & \multicolumn{5}{|c|}{4 inch brick, 1 inch airspace, 4 inch brick, 1 inch lath (no insulation), 5/8 drywall } \\
\hline $1942-1978$ & \multicolumn{5}{|c|}{4 inch brick, 1 inch airspace, 4 inch brick, 1 inch lath (R3 fiberglass), 5/8 inch drywall } \\
\hline post-1978 (no CMU) & \multicolumn{5}{|c|}{4 inch brick veneer, $1 / 2$ inch wood sheathing, $2 \times 4$ stud wall with R-11 insulation, $1 / 2$ drywall } \\
\hline \multicolumn{6}{|l|}{ Frame } \\
\hline \multicolumn{6}{|l|}{ Wall construction } \\
\hline pre-1942 & \multicolumn{5}{|c|}{ white wood siding, $1 / 2$ inch wood sheathing, $2 \times 4$ stud wall no insulation, $5 / 8$ inch drywall } \\
\hline 1942-1978 & \multicolumn{5}{|c|}{ white wood siding, $1 / 2$ inch wood sheathing, $2 \times 4$ stud wall R7 insulation, $5 / 8$ inch drywall } \\
\hline post-1978 & \multicolumn{5}{|c|}{$\begin{array}{l}\text { white wood siding, } 1 / 2 \text { inch wood sheathing, } 2 \times 4 \text { stud wall with R11 insulation, } 1 / 2 \text { inch } \\
\text { drywall }\end{array}$} \\
\hline Insulation & & & & Interzonal & Interzonal \\
\hline Levels & Brick Wall & Frame Wall & Ceiling Insulation & Walls & Floors \\
\hline pre-1942 & 0 & 0 & 0 & 0 & 0 \\
\hline $1942-1978$ & 3 & 7 & 11 & 7 & 11 \\
\hline post-1978 & $\begin{array}{l}\text { Brick vnr+R11 } \\
\text { stud }\end{array}$ & 11 & 30 & 11 & 19 \\
\hline Foundation/Floors & Basement & Crawl & Slab & & \\
\hline pre-1942 & uninsulated & unin/ventil & & & \\
\hline 1942-1978 & uninsulated & unin/ventil & uninsulated & & \\
\hline post-1978 & uninsulated & unin/ventil & & & \\
\hline \multicolumn{6}{|l|}{ Windows \& Shading } \\
\hline pre-1942 & \multicolumn{2}{|c|}{ Double Clear (window+storm) } & & & \\
\hline $1942-1978$ & \multicolumn{2}{|c|}{ Double Clear (window+storm) } & & & \\
\hline post-1978 & \multicolumn{2}{|c|}{ Double Clear (window+storm) } & & & \\
\hline Air Flow & Infiltration & Infil. - 2 story & \multicolumn{2}{|c|}{ Mechanical Ventilation } & \\
\hline pre-1942 & Very Leaky & Leaky & None & & \\
\hline 1942-1978 & Leaky & Typical & Spot & & \\
\hline post-1978 & Typical & Tight & Spot & & \\
\hline Major Appliances & Dryers & & & & \\
\hline pre-1942 & none & & & & \\
\hline 1942-1978 & gas & & & & \\
\hline
\end{tabular}




\begin{tabular}{|l|l|l|l|l|l|}
\hline As-built & & & & & \\
\hline post-1978 & gas & & & & \\
\hline & & & & & \\
\hline Space Conditioning & & & & \\
\hline Heating (gas) & System & Ducts & & \\
\hline pre-1942 & boiler 65\% & None & & \\
\hline $\mathbf{1 9 4 2 - 1 9 7 8}$ & forced air 70\% & Typical/uninsulated & & \\
\hline post-1978 & forced air 78\% & Typical/uninsulated & & \\
\hline & & & & & \\
\hline Cooling & none & & & & \\
\hline pre-1942 & none & & & & \\
\hline $\mathbf{1 9 4 2 - 1 9 7 8}$ & SEER 10 & & & & \\
\hline post-1978 & & & & & \\
\hline & & & & & \\
\hline Water Heating (gas) & 0.48 & & & & \\
\hline pre-1942 & 0.48 & & & & \\
\hline $\mathbf{1 9 4 2 - 1 9 7 8}$ & 0.49 & & & \\
\hline post-1978 & & & & \\
\hline
\end{tabular}

\begin{tabular}{|l|l|l|l|l|l|}
\hline Today & & & & & \\
\hline Building & & & & & \\
\hline $\begin{array}{l}\text { Lot size/dist to } \\
\text { neighbor }\end{array}$ & Size & $\begin{array}{l}\text { Dist to } \\
\text { Neighbor }\end{array}$ & Age & Note & \\
\hline pre-1942 & 25 & 5 & 90 & $25 x 125$ lot, house 20ft wide \\
\hline $\mathbf{1 9 4 2 - 1 9 7 8}$ & 50 & 10 & 50 & & \\
\hline post-1978 & 75 & 20 & 15 & & \\
\hline & & & & & \\
\hline $\begin{array}{l}\text { Beds/Baths and } \\
\text { Garage }\end{array}$ & & & & & \\
\hline Group & Garage & Bed & Bath & & \\
\hline $\mathbf{1}$ & 2 car attached & 3 & 2.5 & & \\
\hline $\mathbf{2}$ & 2 car attached & 3 & 2.5 & & \\
\hline $\mathbf{3}$ & 2 car attached & 4 & 2.5 & & \\
\hline $\mathbf{4}$ & 2 car detached & 3 & 1 & & \\
\hline $\mathbf{5}$ & 2 car attached & 3 & 1.5 & & \\
\hline $\mathbf{6}$ & 2 car attached & 4 & 2.5 & & \\
\hline $\mathbf{7}$ & 2 car detached & 3 & 1 & & \\
\hline $\mathbf{8}$ & 2 car detached & 4 & 2.5 & & \\
\hline $\mathbf{9}$ & 2 car attached & 3 & 3 & & \\
\hline $\mathbf{1 0}$ & 2 car detached & 3 & & & \\
\hline
\end{tabular}




\begin{tabular}{|c|c|c|c|c|c|}
\hline \multicolumn{6}{|l|}{ Today } \\
\hline 11 & 2 car attached & 4 & 2.5 & & \\
\hline 12 & 2 car detached & 3 & 1 & & \\
\hline 13 & 2 car detached & 3 & 1.5 & & \\
\hline 14 & 2 car detached & 3 & 1 & & \\
\hline 15 & 2 car detached & 4 & 2.5 & & \\
\hline Operation & Setpoint Heating & $\begin{array}{l}\text { Setpoint } \\
\text { Cooling }\end{array}$ & MEL & MGL & \\
\hline pre-1942 & 70 & 72 & 1.5 & \multicolumn{2}{|c|}{ Baseline (1.0) } \\
\hline $1942-1978$ & 70 & 72 & 1.5 & \multicolumn{2}{|c|}{ Baseline (1.0) } \\
\hline post-1978 & 70 & 72 & 1.5 & \multicolumn{2}{|c|}{ Baseline (1.0) } \\
\hline & Misc HW Loads & \multicolumn{2}{|c|}{ Natural Ventilation } & & \\
\hline pre-1942 & Sink Aerators & Benchmark & & & \\
\hline $1942-1978$ & Sink Aerators & Benchmark & & & \\
\hline post-1978 & Sink Aerators & Benchmark & & & \\
\hline Walls/Clgs/Roofs & & & & & \\
\hline Brick & $\begin{array}{l}\text { (outside to } \\
\text { inside) }\end{array}$ & & & & \\
\hline Wall construction & & & & & \\
\hline pre-1942 & \multicolumn{5}{|c|}{4 inch brick, 1 inch airspace, 4 inch brick, 1 inch lath (no insulation), 5/8 drywall } \\
\hline 1942-1978 & \multicolumn{5}{|c|}{4 inch brick, 1 inch airspace, 4 inch brick, 1 inch lath (R3 fiberglass), 5/8 inch drywall } \\
\hline post-1978 (no CMU) & \multicolumn{5}{|c|}{$\begin{array}{l}4 \text { inch brick veneer, } 1 / 2 \text { inch wood sheathing, } 2 \times 4 \text { stud wall with R-11 insulation, 1/2 } \\
\text { drywall }\end{array}$} \\
\hline \multicolumn{6}{|l|}{ Frame } \\
\hline Wall construction & & & & & \\
\hline pre-1942 & \multicolumn{5}{|c|}{ white wood siding, $1 / 2$ inch wood sheathing, $2 \times 4$ stud wall no insulation, $5 / 8$ inch drywall } \\
\hline 1942-1978 & \multicolumn{5}{|c|}{ white wood siding, $1 / 2$ inch wood sheathing, $2 \times 4$ stud wall R7 insulation, $5 / 8$ inch drywall } \\
\hline post-1978 & \multicolumn{5}{|c|}{$\begin{array}{l}\text { white wood siding, } 1 / 2 \text { inch wood sheathing, } 2 \times 4 \text { stud wall with R11 insulation, } 1 / 2 \text { inch } \\
\text { drywall }\end{array}$} \\
\hline Insulation & & & & $\begin{array}{l}\text { Interzon } \\
\text { al }\end{array}$ & Interzonal \\
\hline Levels & Brick Wall & Frame Wall & $\begin{array}{l}\text { Attic } \\
\text { Insulation }\end{array}$ & Walls & Floors \\
\hline pre-1942 & 0 & 0 & 7 Blown & 0 & 0 \\
\hline 1942-1978 & 3 & 7 & 19 Blown & 7 & 11 \\
\hline post-1978 & $\begin{array}{l}\text { Brick vnr+R11 } \\
\text { stud }\end{array}$ & 11 & 30 & 11 & 19 \\
\hline
\end{tabular}




\begin{tabular}{|c|c|c|c|c|c|}
\hline Today & & & & & \\
\hline Foundation/Floors & Basement & Crawl & Slab & & \\
\hline pre-1942 & uninsulated & unin/ventil & & & \\
\hline 1942-1978 & uninsulated & unin/ventil & uninsulated & & \\
\hline post-1978 & uninsulated & unin/ventil & & & \\
\hline \multicolumn{6}{|l|}{ Windows \& Shading } \\
\hline pre-1942 & \multicolumn{2}{|c|}{ Double Clear (window+storm) } & & & \\
\hline 1942-1978 & \multicolumn{2}{|c|}{ Double Clear (window+storm) } & & & \\
\hline post-1978 & \multicolumn{2}{|c|}{ Double Clear (window+storm) } & & & \\
\hline Air Flow & Infiltration & Infiltr - 2 story & \multicolumn{2}{|c|}{ Mechanical Ventilation } & \\
\hline pre-1942 & Very Leaky & Leaky & None & & \\
\hline $1942-1978$ & Leaky & Typical & Spot & & \\
\hline post-1978 & Typical & Tight & Spot & & \\
\hline Major Appliances & Dryers & & & & \\
\hline pre-1942 & gas & & & & \\
\hline 1942-1978 & gas & & & & \\
\hline post-1978 & gas & & & & \\
\hline \multicolumn{6}{|l|}{ Space Conditioning } \\
\hline Heating (gas) & System & Ducts & & & \\
\hline pre-1942 & $\begin{array}{l}\text { boiler, } 80 \% \\
\text { AFUE }\end{array}$ & None & & & \\
\hline 1942-1978 & $\begin{array}{l}\text { Furnace } 78 \% \\
\text { AFUE }\end{array}$ & \multicolumn{2}{|c|}{ Typical/uninsulated } & & \\
\hline post-1978 & $\begin{array}{l}\text { Furnace } 80 \% \\
\text { AFUE }\end{array}$ & \multicolumn{2}{|c|}{ Typical/uninsulated } & & \\
\hline \multicolumn{6}{|l|}{ Cooling } \\
\hline pre-1942 & \multicolumn{2}{|c|}{ SEER 10 - window units } & & & \\
\hline 1942-1978 & SEER 10 & & & & \\
\hline post-1978 & SEER 10 & & & & \\
\hline \multicolumn{6}{|l|}{ Water Heating } \\
\hline pre-1942 & 0.54 & & & & \\
\hline $1942-1978$ & 0.54 & & & & \\
\hline post-1978 & 0.54 & & & & \\
\hline
\end{tabular}




\begin{tabular}{|l|l|l|l|}
\hline $\begin{array}{l}\text { Special } \\
\text { Cases }\end{array}$ & \multicolumn{1}{|l|}{$\mid$} & \\
\hline Group 1 & \multicolumn{2}{|l|}{ Median built 1990 - increase walls by 1" foam sheathing, infiltration to tight, and ceiling to R38. } \\
\hline Group 4 & Slab construction fit. Changed to floored attic, R19 (42-78) in roof for both As-built and today. & \\
\hline Group 7 & $\begin{array}{l}\text { Bungalow with upper half story. Added floored attic, no insulation (pre-42). R0 interzonal } \\
\text { walls. }\end{array}$ & \\
\hline Group 11 & MEL =2 to match electric load (lakefront mansion). & \\
\hline Group 14 & $\begin{array}{l}\text { Only building with full/unfinished attic. Added floored attic As-built and flooring + R3 roof for } \\
\text { today. }\end{array}$ \\
\hline
\end{tabular}

\begin{tabular}{|l|l|l|l|l|l|}
\hline Upgrade (options evaluated by BEopt) & & & & \\
\hline Insulation & Brick Wall & Frame Wall & $\begin{array}{l}\text { Attic } \\
\text { Insulation }\end{array}$ & Walls & Floors \\
\hline Levels & & & $\begin{array}{l}\text { R30 or } 38 \\
\text { blown }\end{array}$ & & \\
\hline pre-1942 & & $\begin{array}{l}\text { R30 or } 38 \\
\text { blown }\end{array}$ & & \\
\hline $\mathbf{1 9 4 2 - 1 9 7 8}$ & & $\begin{array}{l}\text { R30 or } 38 \\
\text { blown }\end{array}$ & & \\
\hline post-1978 & & & & \\
\hline Space Conditioning & System & & & & \\
\hline Heating (gas) & Boiler - 95\% AFUE & & & \\
\hline pre-1942 & Furnace - 92.5\% AFUE & & & \\
\hline $\mathbf{1 9 4 2 - 1 9 7 8}$ & Furnace - 92.5\% AFUE & & & \\
\hline post-1978 & & & & & \\
\hline & & & & \\
\hline Cooling & $\begin{array}{l}\text { Premium } \\
(0.67 E F)\end{array}$ & & & & \\
\hline pre-1942 & & & & \\
\hline $\mathbf{1 9 4 2 - 1 9 7 8}$ & SEER 13 & & & & \\
\hline post-1978 & SEER 13 & & & & \\
\hline Water Heating & & & & \\
\hline pre-1942 & & & & \\
\hline $\mathbf{1 9 4 2 - 1 9 7 8}$ & & & & \\
\hline post-1978 & & & & \\
\hline
\end{tabular}




\section{Appendix III - Detailed Results Tables}

BEopt results are presented in this appendix in the same format as the data in Appendix I in order to compare CNT data with modeling results.

\begin{tabular}{|l|l|l|l|l|l|}
\hline & & \multicolumn{5}{|l|}{ Square Footage } \\
\hline GROUP & N Obs & $\%$ of Population & BEopt & CNT Mean & Dev, \% \\
\hline $\mathbf{1}$ & 10856 & $2.5 \%$ & 1740 & 1741 & $0 \%$ \\
\hline $\mathbf{2}$ & 8417 & $1.9 \%$ & 1404 & 1404 & $0 \%$ \\
\hline $\mathbf{3}$ & 20530 & $4.7 \%$ & 2500 & 2506 & $0 \%$ \\
\hline $\mathbf{4}$ & 77435 & $17.9 \%$ & 1196 & 1217 & $-2 \%$ \\
\hline $\mathbf{5}$ & 26445 & $6.1 \%$ & 1304 & 1299 & $0 \%$ \\
\hline $\mathbf{6}$ & 20755 & $4.8 \%$ & 2064 & 2059 & $0 \%$ \\
\hline $\mathbf{7}$ & 50239 & $11.6 \%$ & 1140 & 1141 & $0 \%$ \\
\hline $\mathbf{8}$ & 17629 & $4.1 \%$ & 1872 & 1884 & $-1 \%$ \\
\hline $\mathbf{9}$ & 7318 & $1.7 \%$ & 1800 & 1801 & $0 \%$ \\
\hline $\mathbf{1 0}$ & 9225 & $2.1 \%$ & 1342 & 1349 & $-1 \%$ \\
\hline $\mathbf{1 1}$ & 4544 & $1.1 \%$ & 3168 & 3178 & $0 \%$ \\
\hline $\mathbf{1 2}$ & 101957 & $23.6 \%$ & 1176 & 1185 & $-1 \%$ \\
\hline $\mathbf{1 3}$ & 16411 & $3.8 \%$ & 1584 & 1586 & $0 \%$ \\
\hline $\mathbf{1 4}$ & 48365 & $11.2 \%$ & 1248 & 1254 & $0 \%$ \\
\hline $\mathbf{1 5}$ & 12479 & $2.9 \%$ & 2064 & 2058 & $0 \%$ \\
\hline
\end{tabular}




\begin{tabular}{|l|l|l|l|l|l|l|}
\hline \multicolumn{7}{|l|}{ Source EUI (kBtu/SF) } \\
\hline GROUP & BEopt, As Built & BEopt, Today & CNT Mean & Dev, \% & BEopt Upgrade & Savings \% \\
\hline $\mathbf{1}$ & 127.3 & 132.7 & 126.2 & $5 \%$ & 125.7 & $5 \%$ \\
\hline $\mathbf{2}$ & 156.7 & 164.1 & 176.1 & $-7 \%$ & 153.0 & $7 \%$ \\
\hline $\mathbf{3}$ & 117.6 & 118.7 & 120.2 & $-1 \%$ & 108.2 & $9 \%$ \\
\hline $\mathbf{4}$ & 179.0 & 196.4 & 192.3 & $2 \%$ & 181.6 & $8 \%$ \\
\hline $\mathbf{5}$ & 189.1 & 195.1 & 198.2 & $-2 \%$ & 176.6 & $9 \%$ \\
\hline $\mathbf{6}$ & 141.5 & 155.2 & 147.7 & $5 \%$ & 137.9 & $11 \%$ \\
\hline $\mathbf{7}$ & 216.2 & 224.7 & 227.8 & $-1 \%$ & 182.6 & $19 \%$ \\
\hline $\mathbf{8}$ & 199.3 & 177.1 & 169.3 & $5 \%$ & 141.4 & $20 \%$ \\
\hline $\mathbf{9}$ & 126.3 & 132.0 & 135.7 & $-3 \%$ & 124.4 & $6 \%$ \\
\hline $\mathbf{1 0}$ & 242.1 & 193.9 & 199.1 & $-3 \%$ & 157.9 & $19 \%$ \\
\hline $\mathbf{1 1}$ & 111.9 & 111.8 & 114.0 & $-2 \%$ & 102.1 & $9 \%$ \\
\hline $\mathbf{1 2}$ & 181.5 & 191.0 & 199.0 & $-4 \%$ & 170.4 & $11 \%$ \\
\hline $\mathbf{1 3}$ & 154.0 & 163.9 & 172.0 & $-5 \%$ & 145.7 & $11 \%$ \\
\hline $\mathbf{1 4}$ & 222.5 & 216.4 & 222.9 & $-3 \%$ & 154.8 & $28 \%$ \\
\hline $\mathbf{1 5}$ & 190.4 & 168.6 & 164.8 & $2 \%$ & 131.7 & $22 \%$ \\
\hline
\end{tabular}

\begin{tabular}{|l|l|l|l|l|l|l|}
\hline \multicolumn{7}{|l|}{ Therms (100kBtu) } \\
\hline GROUP & BEopt, As Built & BEopt, Today & CNT Mean & Dev, \% & BEopt Upgrade & Savings \% \\
\hline $\mathbf{1}$ & 1230.5 & 1161.5 & 1077.0 & $8 \%$ & 1052.6 & $9 \%$ \\
\hline $\mathbf{2}$ & 1217.1 & 1146.5 & 1205.0 & $-5 \%$ & 1014.9 & $11 \%$ \\
\hline $\mathbf{3}$ & 1473.9 & 1502.9 & 1446.0 & $4 \%$ & 1279.6 & $15 \%$ \\
\hline $\mathbf{4}$ & 1290.5 & 1215.7 & 1212.0 & $0 \%$ & 1064.9 & $12 \%$ \\
\hline $\mathbf{5}$ & 1597.5 & 1350.6 & 1344.0 & $0 \%$ & 1143.6 & $15 \%$ \\
\hline $\mathbf{6}$ & 1865.7 & 1712.9 & 1553.0 & $10 \%$ & 1405.6 & $18 \%$ \\
\hline $\mathbf{7}$ & 1676.7 & 1430.6 & 1442.0 & $-1 \%$ & 1017.9 & $29 \%$ \\
\hline $\mathbf{8}$ & 2699.8 & 1940.9 & 1757.0 & $10 \%$ & 1355.6 & $30 \%$ \\
\hline $\mathbf{9}$ & 1289.1 & 1209.5 & 1217.0 & $-1 \%$ & 1084.5 & $10 \%$ \\
\hline $\mathbf{1 0}$ & 2366.8 & 1473.6 & 1480.0 & $0 \%$ & 1047.0 & $29 \%$ \\
\hline $\mathbf{1 1}$ & 1696.6 & 1706.0 & 1749.0 & $-2 \%$ & 1436.6 & $16 \%$ \\
\hline $\mathbf{1 2}$ & 1334.5 & 1204.6 & 1268.0 & $-5 \%$ & 1005.6 & $17 \%$ \\
\hline $\mathbf{1 3}$ & 1544.5 & 1395.6 & 1467.0 & $-5 \%$ & 1161.5 & $17 \%$ \\
\hline $\mathbf{1 4}$ & 1950.7 & 1578.7 & 1608.0 & $-2 \%$ & 928.9 & $41 \%$ \\
\hline $\mathbf{1 5}$ & 2854.9 & 2034.9 & 1913.0 & $6 \%$ & 1379.6 & $32 \%$ \\
\hline
\end{tabular}




\begin{tabular}{|c|c|c|c|c|c|c|}
\hline & kWh & & & & & \\
\hline GROUP & BEopt, As Built & BEopt, Today & CNT Mean & Dev, \% & BEopt Upgrade & Savings \% \\
\hline 1 & 7594.0 & 9074.7 & 8887 & $2 \%$ & 9051.2 & $0 \%$ \\
\hline 2 & 7587.9 & 9159.2 & 10076 & $-9 \%$ & 9059.9 & $1 \%$ \\
\hline 3 & 11577.9 & 11607.5 & 12482 & $-7 \%$ & 11455.1 & $1 \%$ \\
\hline 4 & 6373.8 & 9254.1 & 8859 & $4 \%$ & 9120.9 & $1 \%$ \\
\hline 5 & 6285.0 & 9227.1 & 9643 & $-4 \%$ & 9102.6 & $1 \%$ \\
\hline 6 & 7692.5 & 11533.5 & 11714 & $-2 \%$ & 11366.2 & $1 \%$ \\
\hline 7 & 5522.9 & 8724.6 & 8927 & $-2 \%$ & 8468.5 & $3 \%$ \\
\hline 8 & 6817.1 & 10607.6 & 11062 & $-4 \%$ & 10308.0 & $3 \%$ \\
\hline 9 & 7542.6 & 9203.6 & 9719 & $-5 \%$ & 9203.6 & $0 \%$ \\
\hline 10 & 5791.1 & 8771.6 & 9321 & $-6 \%$ & 8600.0 & $2 \%$ \\
\hline 11 & 14743.0 & 14733.4 & 14914 & $-1 \%$ & 14588.0 & $1 \%$ \\
\hline 12 & 5902.6 & 8256.8 & 8483 & $-3 \%$ & 8021.7 & $3 \%$ \\
\hline 13 & 6554.1 & 9367.3 & 9802 & $-4 \%$ & 9074.7 & $3 \%$ \\
\hline 14 & 5637.0 & 8624.4 & 9050 & $-5 \%$ & 8075.7 & $6 \%$ \\
\hline 15 & 7076.7 & 10869.8 & 11348 & $-4 \%$ & 10488.3 & $4 \%$ \\
\hline
\end{tabular}


buildingamerica.gov ENERG Y

DOE/GO-102012-3604 • June 2012

Printed with a renewable-source ink on paper containing at least $50 \%$ wastepaper, including $10 \%$ post-consumer waste. 